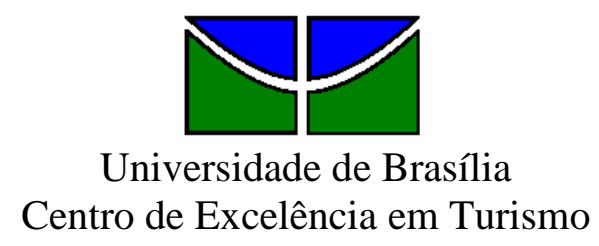

Pós-graduação Lato Sensu

Curso de Especialização em Gestão de Negócios em Turismo

\title{
MINISTÉRIO DO TURISMO E O PROGRAMA NACIONAL DE GESTÃO PÚBLICA E DESBUROCRATIZAÇÃO: a importância da abordagem à qualidade.
}

Ycleda de Oliveira dos Santos

Brasília - 2009 


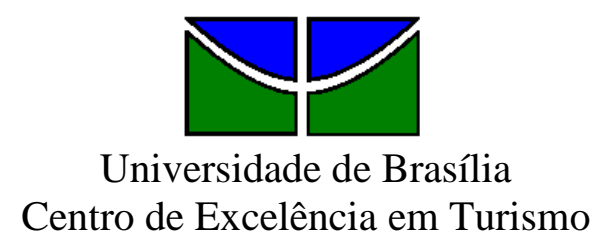

Pós-graduação Lato Sensu

Curso de Especialização em Gestão de Negócios em Turismo

\title{
MINISTÉRIO DO TURISMO E O PROGRAMA NACIONAL DE GESTÃO PÚBLICA E DESBUROCRATIZAÇÃO: a importância da abordagem à qualidade.
}

\author{
Ycleda de Oliveira dos Santos
}

Professor Orientador: José Ricardo Godinho Rodrigues, Dr.

Monografia apresentada ao Centro de Excelência em Turismo da Universidade de Brasília - CET/UnB, como requisito parcial à obtenção do grau de Especialista em Gestão de Negócios em Turismo. 
Santos, Ycleda de Oliveira dos

Ministério do turismo e programa nacional de gestão pública e desburocratização: a importância da abordagem à qualidade / Ycleda de Oliveira dos Santos.

- Brasília, 2009.

81 f. : il.

Monografia (especialização) - Universidade de Brasília, Centro de Excelência em Turismo, 2009.

Orientador: José Ricardo Godinho Rodrigues.

1. Ministério do Turismo. 2. GESPÚBLICA. 3. Qualidade.

I. Rodrigues, José Ricardo Godinho. II. Título 
Universidade de Brasília

Centro de Excelência em Turismo

Pós-graduação Lato Sensu

Curso de Especialização em Gestão de Negócios em Turismo

\title{
MINISTÉRIO DO TURISMO E O PROGRAMA NACIONAL DE GESTÃO PÚBLICA E DESBUROCRATIZAÇÃO: a importância da abordagem à qualidade.
}

\author{
Ycleda de Oliveira dos Santos \\ Aprovado por: \\ Professor Orientador: José Ricardo Godinho Rodrigues, Dr. \\ Professor Avaliador: Alexandre Laval Silva, Dr. \\ Professora Avaliadora: Mara Flora Lottici Krahl, Msc.
}

Brasília, 28 de julho de 2009. 
A Deus em sua unidade trina e à minha mamãe, Adelcy de Oliveira Brito. 
Agradeço ao meu orientador, José Ricardo Godinho Rodrigues, que teve calma e tranqüilidade comigo neste processo. Ao senhor César Viana que se colocou disponível à execução do campo no GesPública. Àqueles que contribuíram diretamente ou indiretamente para a elaboração deste trabalho. E, finalmente, aos meus amigos e familiares por compreenderem os momentos de ausência, pela paciência e sinceridade. 
"Não confunda os objetivos com os meios de atingi-los."

Kaoru Ishikawa 


\section{RESUMO}

A qualidade é buscada pelo humano há muitos séculos por diversos meios e esferas. Em sequiência a esta procura surgiram diferentes métodos de padronização em vista da qualidade e a excelência. No Brasil, o Programa Nacional de Gestão Pública e Desburocratização (GesPública) emerge da preocupação de alcançar a qualidade em serviços e resultados públicos e de diminuir os excessos de burocracia. De outro lado encontra-se a atividade turística, esta por sua vez, ganhou espaço pouco a pouco ao longo dos séculos tendo como motivos para esta afirmação a expansão de algumas satisfações das necessidades humanas, a fixação de férias, a disponibilidade de tempo e por fim a necessidade do ser humano em fugir da monotonia cotidiana. A grandiosidade do turismo, no século XXI, fez com que o governo brasileiro percebesse as demandas e as ofertas envolvidas nesta atividade, esta percepção se transformou em preocupação e em conseqüência na composição do Ministério do Turismo (MTUR). Esta entidade por sua vez, como órgão público possui diretrizes, metas, objetivos e estrutura organizacional para fomentar o turismo nacional, porém estes não são na sua totalidade direcionados ao padrão de qualidade do governo federal. Além disso, os cidadãos estão cada vez mais exigentes com relação às atividades e serviços realizados pelas entidades públicas, uma vez que estes órgãos, muitas vezes, esbanjam burocracia e carecem de eficiência e eficácia em suas principais atividades. Este projeto visa demonstrar a importância de um órgão tão abrangente em adequar-se ao GesPública, visando a qualificação em sua estrutura organizacional. Isto através da análise da estrutura do Ministério do Turismo e da aplicação do GesPública. Em face do instrumento GesPública, o MTUR poderá desenvolver as metas e os reais objetivos do turismo brasileiro de forma sistêmica e rápida. Por meio do estímulo dos módulos estruturais já existentes e do estabelecimento de novos critérios intra e extra organizacional, o MTUR focará ainda mais o cidadão, assim ele atingirá os clientes externos: cidadão e a sociedade brasileira, clientes de sua oferta; com resultados mais concisos e palpáveis da atividade no País. 


\begin{abstract}
The human quality is fetched by many centuries by various means and spheres. In sequence to this search different standardization methods have emerged in view of quality and excellence. In Brazil, the national programme for public administration and bureaucracy (GesPública) emerges from concern to achieve quality public services and results and reduce the excessive bureaucracy. On the other hand is the tourist activity, this in turn, won space gradually over the centuries as reasons for this expansion of some satisfaction of human needs, holidays, the availability of time and finally the need for humans to flee the day-to-day monotony. The grandeur of the 21st century tourism, the Brazilian Government to understand the demands and offerings involved in this activity, this perception is concern and consequently in the composition of the Ministry of tourism (MTUR). This entity in turn, as a public body has guidelines, goals, objectives and organizational structure to foster national tourism, but these aren't in its entirety directed to the standard of quality of the Federal Government. In addition, citizens are increasingly demanding with regard to activities and services performed by public authorities, since these bodies often esbanjam bureaucracy and lack of efficiency and effectiveness in its main activities. This project aims to demonstrate the importance of an organ as far-reaching in sticking to GesPública for qualification in its organizational structure. This by analysing the structure of the Ministry of tourism and implementation of the GesPública. In view of the GesPública, MTUR instrument may develop goals and the Brazilian real goals of tourism and systemic way quickly. By means of stimulating structural existing modules and the establishment of new organizational intra and extra criteria, the MTUR further citizen deals, so it will reach external clients: citizen and Brazilian society of clients; with more concise and tangible results of the activity in the country.
\end{abstract}

Keywords:

1. Ministry of tourism
3. Quality 


\section{SUMÁRIO}

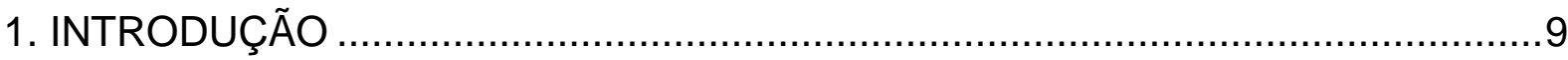

1.1. Contextualização do Assunto/ Apresentação e delimitação do tema ............................. 9

1.2. Descrição da Situação problemática/ Formulação do problema ...................................... 10

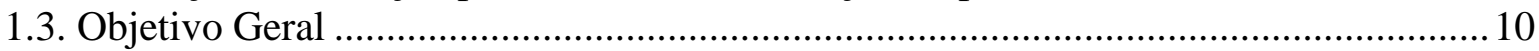

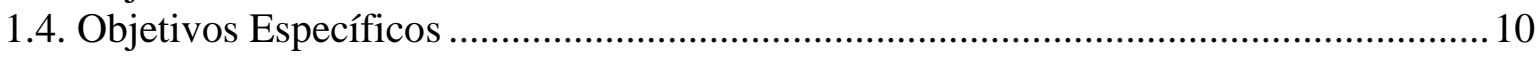

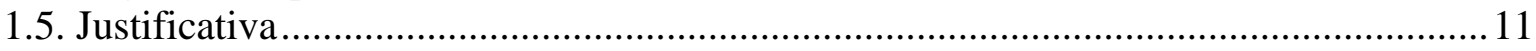

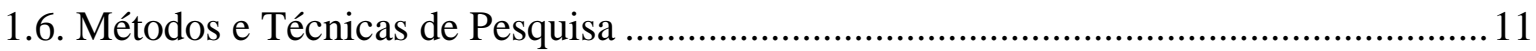

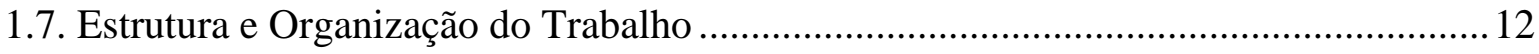

2. REFERENCIAL TEÓRICO .................................................................... 13

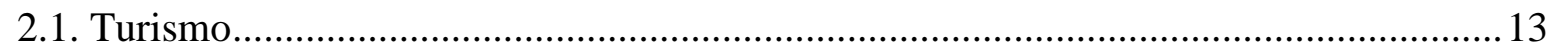

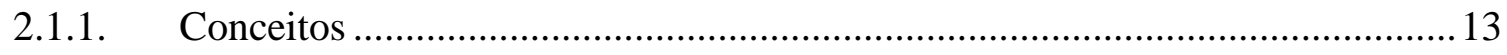

2.1.2. Evolução Histórica do Turismo no Mundo e no Brasil .................................... 14

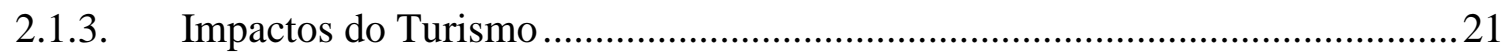

2.1.4. Ministério do Turismo - Plano Nacional do Turismo e Estrutura Organizacional 23

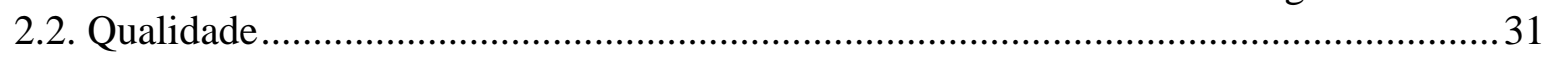

2.2.1. História da Gestão pela Qualidade ..................................................................... 31

2.2.2. Programa Nacional de Gestão Pública e Desburocratização (GESPÚBLICA) ..... 38

2.3. Ministério do Turismo X Programa Nacional de Gestão Pública e Desburocratização 49

3. MÉTODOS E TÉCNICAS DE PESQUISA .................................................. 57

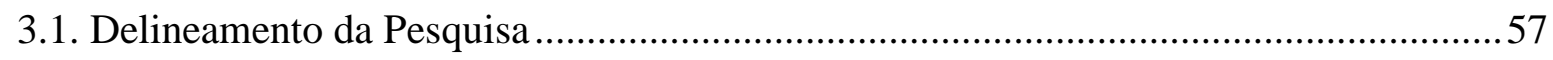

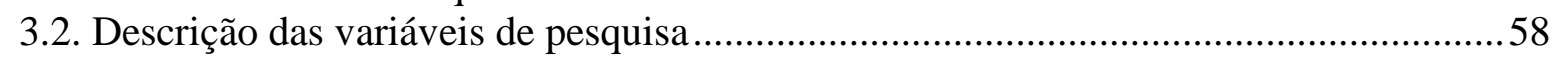

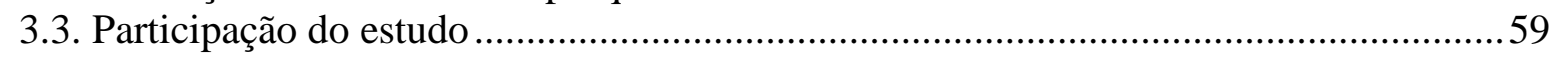

3.4. Procedimentos e instrumentos utilizados na Coleta e Análise de dados .......................59

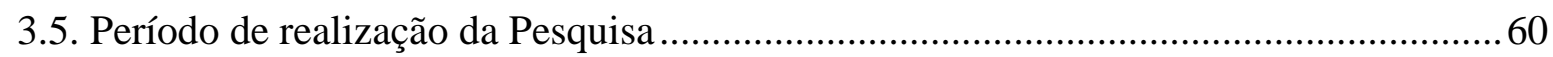

3.6. Comentários sobre o Processo de Coleta de dados........................................................... 60

4. APRESENTAÇÃO E ANÁLISE DOS DADOS .............................................61

4.1. Agrupamento, ordenação e descrição dos dados coletados .........................................61

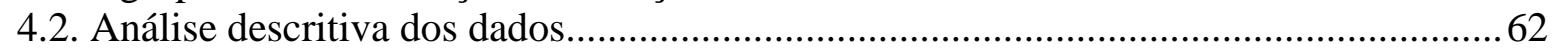

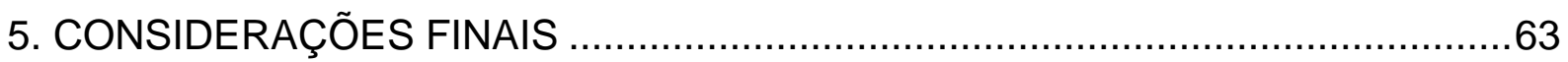

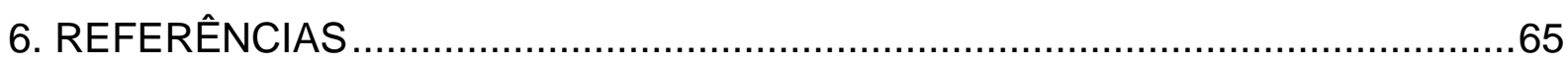

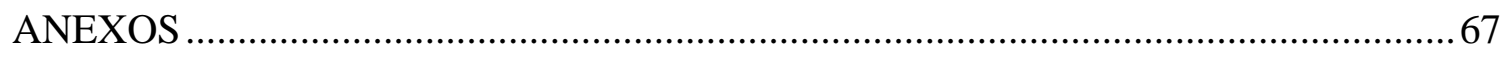

Anexo A: Competências dos Departamentos do Ministério do Turismo ..........................67

Anexo B: Decreto No5378 de 23 de fevereiro de 2005, Gespública. ................................ 76

Anexo C: Decreto de 17 de março de 2009, Ano Nacional da Gestão Pública. ............... 78

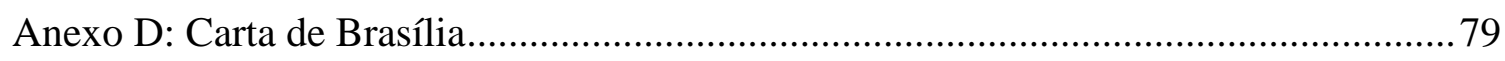




\section{INTRODUÇÃO}

\subsection{Contextualização do Assunto/ Apresentação e delimitação do tema}

Há alguns anos e, ainda hoje a gestão pública sofre com a burocracia de seus atos simples e em conseqüência dos mais complexos, ou seja, àqueles que envolvem grande potencial intelectual. No Brasil, as ações de melhoria, qualidade nos métodos e em especial no serviço público surgiram desde a década de 50 do século passado, e aos poucos o governo federal vem aprimorando suas políticas para alcançar este objetivo.

No ano 2005, surge o Programa Nacional de Gestão Pública e Desburocratização, Gespública, que ratifica as ações voltadas para a qualidade em serviços públicos e a desburocratização, finalizando a identificação e otimização dos processos realizados no serviço público federal e regional como um todo. Hoje, este mesmo programa é referência nacional, juntamente com o Programa da Fundação Nacional da Qualidade (FNQ), para empresas privadas em aprimoramento de seus objetivos.

Outro dado notório é o Decreto de 17 de março de 2009, que institui este ano como voltado ao Gespública na administração pública federal em seus variados níveis organizacionais.

Ao par deste desencadeamento de melhorias no serviço público, o turismo ganha um espaço até então não dedicado a ele. As pessoas precisam viajar, sair do ambiente cotidiano e fazem isso realizando turismo. O turismo é uma atividade econômica possuidora de grande rentabilidade no mundo, sendo que existem países que o priorizam e aqueles que o deixam como segunda opção. Ao observar os impactos econômicos e influências desta atividade o governo brasileiro, em 2003, decidiu criar um ministério para o turismo no intuito de desenvolver esta atividade em nível nacional.

Assim como vários órgãos, o Ministério do Turismo deve se organizar, planejar suas atividades e executá-las de forma eficiente e eficaz com foco para o cidadão, cliente externo. Isso, sempre, para o alcance de suas metas nacionais prioritárias.

A pesquisa é dividida em dois momentos, um bibliográfico e outro em campo. A bibliografia e a análise de dados disponíveis pelo site do Ministério do Turismo e da Organização Mundial do Turismo permitem a visualização, contextualização e abordagem conceitual preliminar do tema, com fins de compreender os assuntos gerais e específicos da pesquisa. A pesquisa de campo é necessária para o levantamento e descrição da aplicação do Programa a partir do 
Ministério do Planejamento, Orçamento e Gestão (MPOG), por meio da Secretaria de Gestão (SEGES).

A SEGES é a secretaria do MPOG que cuida da análise, avaliação e implementação de formas de gestão pública voltadas para a desburocratização, a qualidade em prestação de serviços e a boa aplicação dos rendimentos públicos para o alcance de suas metas e objetivos direcionados ao cidadão (MPOG, 2009).

A concretização desta pesquisa deu-se por entrevistas em questionários específicos do órgão SEGES. Possibilitando uma real percepção das hipóteses levantadas, caso verídicas ou não.

\subsection{Descrição da Situação problemática/ Formulação do problema}

Diversos autores de referência à administração pública, admitem o método por processos como um meio eficaz para o alcance da qualidade nos objetivos na organização. Há alguns anos o Gespública oferta sua concepção ideológica de trazer a qualidade aos serviços públicos tendo foco no cliente externo, a partir da desburocratização no ambiente público federal, porém, nem todos os órgãos do governo são adeptos ao programa. De fato o Ministério do Turismo, em seu ambiente de estratégia, não está totalmente adeso neste Programa. Em vista disto, este estudo vem demonstrar a importância da aplicação do Programa Nacional de Gestão Pública e Desburocratização no Ministério do Turismo brasileiro.

\subsection{Objetivo Geral}

Demonstrar a importância da adesão ao Programa Nacional de Gestão Pública e Desburocratização (GESPÚBLICA) pelo Ministério do Turismo.

\subsection{Objetivos Específicos}

- Contextualizar o Turismo no Brasil.

- Expor as metas do Plano Nacional de Turismo, realizadas pelo Ministério do Turismo.

- Apresentar a estrutura organizacional do Ministério do Turismo.

- Abordar, de maneira simplificada, o tema qualidade.

- Apresentar o Programa Nacional de Gestão Pública e Desburocratização (Gespública). 
- Apontar os benefícios da adesão do Ministério do Turismo (MTUR) ao Programa.

\subsection{Justificativa}

Esta pesquisa dá-se em um momento de grandes mudanças na visualização, percepção e exigências dos cidadãos aos órgãos públicos com relação a sua prestação de serviços públicos. Não longe desta realidade, de constante mutação, encontra-se o turismo, atividade em gigante crescimento mundial e a evolução da qualidade, de programa e prêmios de reconhecimento desta no mundo.

A par destes acontecimentos há o Gespública, um programa que finaliza, por meio de processos, dentre outras orientações, diminuir a burocracia, focar a excelência para atender o cidadão. Portanto, a aplicação deste modelo é essencial ao órgão de turismo no Brasil.

O resultado obtido desta pesquisa será necessário como respaldo ao próprio Ministério, caso este órgão esteja agindo em conformidade ao padrão oficial de qualidade em serviços e de auxílio para mudança de postura, se necessário, e aos interessados em seu ambiente organizacional.

\subsection{Métodos e Técnicas de Pesquisa}

Pesquisa de cunho bibliográfico, documental e a campo. O levantamento bibliográfico sobre o turismo situa a atividade no cenário brasileiro e sua importância para este País. O referencial teórico sobre a evolução da qualidade, sua importância, o aparecimento do Gespública e da Desburocratização permitem perceber a ação deste programa no Brasil. A partir da equiparação dos dois temas é possível perceber a necessidade de adequação ao Programa pelo Ministério do Turismo.

A coleta de dados foi por pesquisa qualitativa, com entrevista, questionário fechado junto aos responsáveis pelo Gespública, da Secretaria de Gestão órgão vinculado ao Ministério do Planejamento, Orçamento e Gestão. E intencionou-se, porém não se conseguiu efetivar, uma entrevista com os responsáveis pela gestão administrativa do Ministério do Turismo. 


\subsection{Estrutura e Organização do Trabalho}

A monografia se estrutura em quatro capítulos. No primeiro capítulo é abordado o referencial teórico em que constam três subtítulos. O primeiro tráz o conceito da atividade turística, sua contextualização histórica mundial e brasileira. A criação do Ministério do Turismo (MTUR) e sua estrutura organizacional.

Em um segundo momento, expõe-se o tema qualidade, seu conceito e evolução histórica abordando o Programa Nacional de Gestão Pública e Desburocratização (GESPÚBLICA) e a Desburocratização, para uma compreensão global de sua aplicabilidade e importância.

Numa terceira fase são colocados frente à frente o MTUR e o GESPÚBLICA, demonstrando a sua necessidade no Ministério e possíveis aplicações.

No segundo capítulo é colocada a metodologia utilizada nesta pesquisa.

No terceiro capítulo é apresentada a saída à campo, no Ministério do Planejamento, Orçamento e Gestão pelo GESPÚBLICA. Esta saída visa a visualização da aplicação do programa por parte dos órgãos envolvidos.

Por fim há a conclusão do estudo, a partir da bibliografia exposta e da exploração em campo sobre a aplicabilidade do Programa pela Secretaria de Gestão (SEGES), demonstrando a importância do programa para o Ministério. 


\section{REFERENCIAL TEÓRICO}

\subsection{Turismo}

\subsubsection{Conceitos}

O Turismo é uma atividade rentável economicamente para os países que dispõem de infraestrutura adequada e atrativos turísticos. Ele está entre as atividades econômicas que mais crescem no mundo, demonstrando sua eficiência e eficácia junto à economia mundial. Seu poder agregador social pode contribuir para a diminuição das grandes diferenças que há entre classes sociais e econômicas.

Em 1942, alguns professores da Universidade de Berna, traziam o seguinte conceito de turismo, "a soma de fenômenos e de relações que surgem das viagens e das estâncias dos não residentes, desde que não estejam ligados a uma residência permanente nem a uma atividade remunerada" (Hunziker e Krapf apud Organização Mundial do Turismo, 2001, p. 37). Não muito longe desta essência, em 1981, a atividade era definida como "os deslocamentos curtos e temporais das pessoas para destinos fora do lugar de residência e de trabalho e as atividades empreendidas durante a estada nesses destinos" (Burkart e Medlik apud Organização Mundial do Turismo, 2001, p. 37). É importante lembrar que a atividade naquele período era em menor fluxo e rentabilidade do que hoje e seu contexto sociocultural era outro.

Em 1993, a World Tourism Organisation - W.T.O. apud Youell (2002, p. 29) afirmou que o turismo compreende "[...] as atividades de pessoas que estão viajando e vão se hospedar em lugares fora do ambiente habitual em que vivem por não mais que um ano consecutivo, por motivos de lazer, negócios e outros”. Um ano depois, a Organização Mundial do Turismo O.M.T. - (2001, p. 38) retratou que "o turismo compreende as atividades que realizam as pessoas durante suas viagens e estadas em lugares diferentes ao seu entorno habitual, por um período consecutivo inferior a um ano, com finalidade de lazer, negócios ou outras”. Estes dois últimos conceitos são necessários e notórios à caracterização da atividade turística e futuramente do turista e tudo que os envolve.

Logo o turismo é composto por diversas variáveis, a primeira o indivíduo que se desloca de um local a outro; a motivação do viajante; o local, cidade visitada; e os equipamentos que permitem a concretização da atividade turística, como hotéis, restaurantes, etc.

Segundo McIntosh e Gupta apud Lage e Milone (2000, p. 26), "o turismo, de forma ampla, é assumido como a ciência, a arte e a atividade de atrair, transportar e alojar visitantes, a fim de 
satisfazer suas necessidades e seus desejos". Esta necessidade de saciar e superar as expectativas dos visitantes em sua estada remete à sustentabilidade, uma vez que a comunidade envolvida necessita dos recursos, sejam eles sociais, culturais, materiais, econômicos ou naturais capazes de resgatar e distribuir a realidade do local.

Assim o mercado turístico é bastante segmentado, para melhor atender seus clientes e seus respectivos desejos. As segmentações são diversas e de acordo com Lage e Milone (2000), elas são divididas em segmentação geográfica, ligadas à área geográfica e suas características físicas; demográfica, composta pela idade, sexo, profissão, entre outros fatores sóciodemográficos; psicológica, associada à psique humana, ou seja, às vontades individuais; econômica, esta em virtude das faixas econômicas da sociedade; e social vinculado ao status, aos hábitos culturais acrescidos de intelectualidade.

\subsubsection{Evolução Histórica do Turismo no Mundo e no Brasil}

Há várias teorias para citar o local exato do vicejar da atividade turística. Alguns autores reportam à Fenícia, outros à Grécia e até Roma. Um fator é conciso e determinante, o turismo surge a partir do momento que o ser humano se desloca de um local a outro e isso começou há vários séculos.

Para Dias (2008) o turismo surgiu na Grécia antiga a partir das visitações ao Oráculo de Delfos, da participação em Olimpíadas e dos filósofos que tratavam de obter o saber em lugares longe de sua residência fixa. Esta atividade turística fora mais consolidada em Roma, onde os habitantes possuíam uma segunda casa em locais longínquos de suas residências. Para dar suporte a estas movimentações turísticas, aos segundos lares e seus habitantes, era necessária uma mínima estrutura física sanitária e turística local, com alojamentos e alimentação.

Segundo o mesmo autor, após a queda de Roma e das invasões bárbaras surgiram os feudos, que dificultavam a movimentação dos indivíduos por outros lugares, inviabilizando a integração regional inclusive economicamente. Deste período até o século XV, datam as grandes navegações com objetivos religiosos e comerciais.

Nos séculos XVII e XVIII se intensificam os deslocamentos para a Europa, Grécia e Oriente Médio, pois os filhos das famílias nobres viajavam em busca de estudos de qualidade em outros lugares e assim "inicia um tipo de viagem que tem relação direta com o surgimento do 
turismo moderno" (DIAS, 2008, p.33). Neste último, com o crescimento turístico e a ascensão da burguesia, as viagens passam a ter um fim mais tecnológico e científico, porém surge uma certa expectativa sobre a natureza e os círculos sociais envolvidos em que os turistas começam a explorar. Época, em que eles procuravam afastar-se dos lugares industrializados e recorriam ao turismo à beira-mar, classificado como sol e praia.

A Revolução Industrial, no século XIX, traz impactos benéficos ao turismo: a mão-de-obra passa a ser assalariada, possibilitando aos indivíduos de diversas classes sociais a acessibilidade à atividade. A cidade torna-se mais desenvolvida em seus aspectos sanitários e estruturais e com o tempo livre definido os indivíduos têm-se um maior interesse em viajar. Neste período também surge a palavra turismo, como definidora da atividade até então comercial. "Os movimentos que continuam em pleno século XXI foram desenvolvidos principalmente no século XIX: termalismo, cassinismo, paisagismo e montanhismo" (REJOWSKI; YASOSHIMA; STIGLIANO; SILVEIRA in REJOWSKI, 2002, p. 68). Não somente as espécies de atividades turísticas modernas surgem nesta época, como também novas formas de comercializar o turismo, neste período ascendem as agências de viagens, tendo como pioneiro Thomas Cook, a utilização de meios ferroviários e hidroviários como transportes, restaurantes e hotéis de luxo, surgem inclusive guias de viagens e clubes, que trazem em conseqüência a execução de grandes eventos e um fomento ao turismo até então desconhecido.

No início do século XX, houve a intensificação da demanda e em seguida, o crescimento imobiliário. Ruschmann (2003, p. 20), comenta que, “[...] a natureza é domesticada, porém, não necessariamente esquecida, pois as empresas turísticas limitavam seus produtos às estações e ao seu entorno, onde a natureza e as civilizações tradicionais tinham seus direitos garantidos". Esta proposição dá base para afirmar que as tendências naturais foram parcialmente abaladas, mas não destruídas neste momento.

Ainda no século XX, o turismo sente algumas intervenções de fluxo e demanda. Esta atividade vinha crescente até a Primeira Guerra Mundial, em que muitos hotéis pararam suas atividades normais para abrigar tropas ou hospitais (SOLHA in REJOWSKI, 2002). Após a guerra, o turismo volta a crescer "mas o crescimento do turismo foi novamente abalado pela depressão econômica ocasionada pela quebra da Bolsa de Valores de Nova York.”, conforme Solha (in REJOWSKI, 2002, p.73). Os anos seguintes à crise de 1929 foram difíceis para o desenvolvimento do turismo e a atividade veio a se restabelecer, ainda não totalmente, por volta de 10 anos depois. 
Entre as décadas de 20 e 40, a invenção do automóvel aproximou várias camadas sociais na atividade turística, e a construção de rodovias aumentou significativamente o fluxo turístico mundial, originando assim o turismo de circuitos.

No decorrer do período da Segunda Guerra Mundial, a partir dos movimentos trabalhistas, foram regulamentadas as férias remuneradas e obrigatórias ao trabalhador assalariado, disponibilizando assim tempo para o turismo aos indivíduos que ainda não tinham acesso.

Em 1945, o avião foi lançado como meio de transporte, o turismo de massa cresce nos países industrializados, e o próprio entra na “[...] fase de 'indústria de serviços', sendo controlada por agências ou operadores turísticos que dirigem e manipulam a oferta e a demanda turística" (DIAS, 2008, p. 38). Neste período o poder de compra aumenta e a busca pelo bem-estar e pela paz firmou-se em todo o mundo, originam-se os vôos charters $^{1}$ e com eles os pacotes turísticos, em consequiência disso o turismo nacional e internacional multiplicam-se.

Nas décadas de 50 até 70, ocorreu um aumento exagerado na demanda turística, a massificação, a qual caracterizou a degradação ambiental em potenciais turísticos e seus recursos naturais. Neste momento, então, é latente os excessos de carga nos litorais e montanhas.

Nos anos 70 e 80, a política de cooperação internacional é intensificada. Em 1973, o preço do petróleo sobe e o turismo decresce ficando em recessão até 1978. Com os aparelhos turísticos, até então desenvolvidos com base no petróleo e este último com alto preço, há diminuição significativa do fluxo turístico prejudicando alarmantemente a atividade e seus lucros. Esta posição desmerecedora muda a partir de 1978, ano em que o petróleo recupera um valor mais acessível. Em 1974 emerge a Organização Mundial do Turismo (O.M.T.), que tenta solucionar algumas problemáticas encontradas. Após este período de conturbações e possíveis soluções a prosperidade econômica dos países desenvolvidos alavanca o turismo, e a partir de 1985 uma pequena visão sustentável ronda os pensamentos dos visitantes e dos planejadores, isso possibilita uma discreta estima dos locais visitados e a conservação dos mesmos.

Ruschmann (2003, p. 20) afirma que:

[...] o turismo de natureza ou o turismo ecológico ocorre na maioria das localidades turísticas estabelecidas e, nas novas, evita-se a ocupação de todos os espaços. [...] A natureza e todos os seus

\footnotetext{
${ }^{1}$ Os vôos charters se caracterizam por aviões que são fretados para uma dada localidade, isso torna a viagem mais barata do que os vôos regulares e em consequiência as passagens aos viajantes.
} 
componentes tonam-se pretextos para a descoberta, a iniciação, a educação e o espírito de aventura e, dessa forma, dão origem a um novo mercado.

Esta nova fase do turismo, demonstra o início da conscientização do turista consumidor que a partir deste momento preocupa-se com o espaço natural e com a qualidade do produto oferecido. Em 1990, é criada a World Travel Tourism and Council ${ }^{2}$ (W.T.T.C.). Da década de 90 até o século XXI, a atividade é focada na natureza, seus observadores e freqüentadores estão mais exigentes e uma ação que não seja ambientalmente correta de seus fornecedores de serviços pode influenciar negativamente a demanda daquele.

No início do século XXI, observa-se a necessidade das organizações turísticas internacionais, sua coordenação e regulamentação em nível mundial e o aumento massivo do turismo ecológico. Isso ocorre porque a globalização está interligada na revolução técnico-científica que possibilita uma informação mais rápida sobre os locais. Os indivíduos têm maior tempo livre, a renda é maior, diminuíram as exigências aduaneiras, há mais urbanização nos países e as árvores presentes na cidade diminuíam gradativamente, fazendo com que as pessoas procurem um turismo mais voltado à observação e ao contato com o meio ambiente natural, em seu tempo livre.

Desta maneira, o turismo sustentável é a forma mais visada, desta atividade, pelas empresas, tornando-se a mais rentável mundialmente, estando no topo e ultrapassando outras que em demasiadas épocas eram de fundamental importância para o desenvolvimento social.

Já no Brasil, o turismo se iniciou com a vinda da família real portuguesa para o continente em busca de exílio, pois o país ficou mais visível como atrativo turístico naquele momento. Camargo explica,

O Brasil deixará desvendar-se para o mundo em 1808. Isso se fará, marcadamente, pela presença européia e, em particular, inglesa. Os portos abertos para o comércio de mercadorias, abolidas as restrições, se abrem igualmente para a circulação de homens. O que é particularmente mais relevante para o tema ora abordado são os olhares desses outros homens, não brasileiros ou portugueses, que irão criar representações do Brasil. Produzirão literatura que circulará em textos escritos com representações plásticas que o ilustram, ou em

\footnotetext{
2 "É composta por executivos das principais companhias internacionais de aviação, transportes, hotéis e agências de viagens, sediado em Bruxelas. É a primeira organização do setor privado cujos objetivos, são entre outros, a realização de mudanças no setor público em assuntos como a melhoria de reconhecimento da importância do turismo e a eliminação de barreiras que restringem o crescimento do turismo entre outros." (O.M.T., 2001, p. 119).
} 
gravuras e pinturas autônomas, que cristalizarão cumulativamente no decurso do tempo imagens culturalmente diferenciadas, exóticas. Isto é, imagens daquilo que ao era característico dos seus locais de origem, e que para o seu olhar seria estranho, ou estrangeiro (2007, p. 57).

Entretanto, ao se analisar a fundo este fato percebe-se que o turismo começou bem antes, talvez com Pedro Álvares Cabral que veio em busca de novas terras com sua caravana, expondo bem a atividade turística em sua essência etimológica.

Para Trigo (2002), pelo fato do Brasil possuir uma situação desfavorável sócioeconômicamente e por algumas conseqüências determinadas por esta situação, como a violência, há uma diminuição motivacional dos turistas em conhecer o país.

Para visualizar bem a situação brasileira no turismo, é necessário analisar tabelas como a abaixo, em que o Instituto Brasileiro de Turismo em parceria com a Polícia Federal expõe a chegada, em números, de turistas no país nas últimas décadas.

Figura 1: Chegada de Turistas ao Brasil - 1970 -2007.

\begin{tabular}{l|r|r|r|r|r|r|r|}
\hline \multicolumn{1}{c|}{} & \multicolumn{1}{c}{ Chegadas de turistas } \\
\hline Ano & \multicolumn{1}{|c|}{ Total } & Ano & Total & Ano & Total & Ano & Total \\
\hline 1970 & 249.900 & 1975 & 517.967 & 1980 & 1.625 .422 & 1985 & 1.735 .982 \\
1971 & 287.926 & 1976 & 555.967 & 1981 & 1.357 .879 & 1986 & 1.934 .091 \\
1972 & 342.961 & 1977 & 634.595 & 1982 & 1.146 .681 & 1987 & 1.929 .053 \\
1973 & 399.127 & 1978 & 784.316 & 1983 & 1.420 .481 & 1988 & 1.742 .939 \\
1974 & 480.267 & 1979 & 1.081 .799 & 1984 & 1.595 .726 & 1989 & 1.402 .897 \\
\hline
\end{tabular}

\begin{tabular}{|c|c|c|c|c|c|c|c}
\hline Ano & Total & Ano & Total & Ano & Total & Ano & Total \\
\hline 1990 & 1.091 .067 & 1995 & 1.991 .416 & 2000 & 5.313 .463 & 2005 & 5.358 .170 \\
1991 & 1.228 .178 & 1996 & 2.665 .508 & 2001 & 4.772 .575 & 2006 & 5.017 .251 \\
1992 & 1.692 .078 & 1997 & 2.849 .750 & 2002 & 3.784 .898 & 2007 & 5.025 .834 \\
1993 & 1.641 .138 & 1998 & 4.818 .084 & 2003 & 4.132 .847 & & \\
1994 & 1.853 .301 & 1999 & 5.107 .169 & 2004 & 4.793 .703 & & \\
\hline
\end{tabular}

Fonte: Departamento de Polícia Federal e Instituto Brasileiro de Turismo in Anuário Estatístico. EMBRATUR. Volume 35. 2008, p. 126. 
Ao analisar os dados contidos na tabela acima, de chegadas de turistas no Brasil nas décadas de 1970 a 2000, é possível perceber alguns anos em que esta atividade ficou em baixa. Nos anos de 1973, 1975 e 1976, em que o mundo turístico sofria drasticamente as consequiências de uma crise no petróleo, o Brasil crescia de forma moderada, porém não correspondente às previsões dos anos anteriores e posteriores.

Em 1981, 1982, de 1987 a 1990 e 1993 a atividade turística tem um decréscimo significativo em recebimento de turistas. Na década de 80 , os países investiam significativamente na atividade turística, de acordo com o desenvolvimento econômico, e o Brasil ficava abaixo dos 10 maiores destinos da América Latina, recebendo e enviando poucos turistas.

No ano de 1991, estudiosos alertaram os governantes a respeito do crescimento da pobreza extrema no Brasil. Segundo Trigo (2002, p. 29), no relatório de desenvolvimento humano proferido pela $\mathrm{ONU}^{3}$ em 1997, o Brasil ficou em 68 lugar do total de 173 países. Este relatório expõe a situação da população de um país em fatores específicos e diretamente influencia a decisão de compra dos turistas internacionais.

As crises políticas daquela década atingiram fatores importantes. Neste momento os países aspiravam novas ideologias de conservação e preservação da natureza, porém no Brasil, apoiada pelo governo da época, a devastação da Amazônia realizada por empresas de extração, foi um dos motivos que fez o turista repugnar sua vinda ao país; outro motivo foi o aumento da criminalidade nos grandes centros.

Em toda a década de 90, os estados nordestinos fizeram propaganda desvinculada do Rio de Janeiro - que possui a maior parte das características citadas acima -, e executavam melhorias em todos atrativos dos estados para conforto do turista.

A Política Nacional do Turismo, criada em 1996 e desenvolvida pela Embratur, estendeu estes primeiros avanços turísticos auxiliando no crescimento da atividade, conscientização da capacidade de agregador social e econômico para o Estado. Para Trigo (2002, p. 40) “os grandes desafios para o desenvolvimento pleno do turismo no país são a preservação ambiental, a qualidade dos serviços turísticos e a capacitação profissional em larga escala e em todos os níveis". A crise econômica em 1999 preocupou os investidores brasileiros, mas o País se estabilizou cambialmente, o turismo obteve queda na visita de turistas estrangeiros, sendo demonstrado pelo início de algumas crises financeiras nas companhias aéreas nacionais.

\footnotetext{
${ }^{3}$ Organização das Nações Unidas
} 
Após esta fase, uma queda do fluxo de demanda, é sentido nos anos, 2001, 2002 e 2006, o que possivelmente reflete período pós-crise e troca de governo.

Para Trigo,

O censo de 2000 mostrou que persistem no Brasil os graves problemas estruturais, como as diferenças sociais e a violência. No setor empresarial persistem um certo amadorismo, falta de qualidade, formação profissional deficiente e velhos feudos burocráticos das instâncias governamentais que, especialmente nas regiões mais atrasadas, são um entrave ao desenvolvimento (2002, p. 43).

Após uma grande fase de turbulências de como desenvolver o turismo, o mesmo inicia seu fomento, porém com outros problemas, sendo destacado o turismo brasileiro ao nível internacional com seus profissionais. Neste momento, a desenvoltura profissional e a postura do governo restringe os avanços da atividade turística cultivando um idealismo do que se é e como irá ficar.

Por volta de 2003, surge o Ministério do Turismo (MTUR), com o Programa "Roteiros Integrados" que explorou áreas até então não investigadas em seu potencial turístico. Vários planos foram lançados com a intenção de crescer as opções e a demanda nacional turística, tais ações foram positivas incentivando a população e os turistas estrangeiros a realizarem viagens no território brasileiro.

Em 2007 a crise aérea explodiu, após alguns acidentes fatídicos envolvendo dezenas de indivíduos conturbando a situação brasileira. Porém não foi comprovada estatisticamente a queda do fluxo turístico no Brasil, mas, sim, uma busca por outras alternativas de transporte.

Em nível estrutural, os problemas socioeconômicos, como a má distribuição de renda e a injustiça social prejudicam não só a população brasileira, mas também o fluxo turístico de entrada no país.

O tráfico e a violência em vários setores sociais crescem em grandes proporções, a mídia internacional não perde um detalhe, toda a defasagem social do Brasil é publicada ao mundo e conseqüentemente poucos indivíduos arriscam visitar o país. Trigo (2002, p. 38) afirma que “as pessoas são sensíveis a determinados problemas em viagens, especialmente aos que afetam sua segurança”. Isso diminui o fluxo econômico que o turismo proporciona aos envolvidos. 


\subsubsection{Impactos do Turismo}

O turismo está em constante mudança, influenciando os agentes sociais, naturais e econômicos de uma comunidade tanto positiva quanto negativamente, cabendo aos responsáveis identificar os aspectos degradantes e transformá-los em benfeitorias à região. Dentre os principais impactos gerados pelo turismo existem os impactos no meio-ambiente e no ambiente econômico.

\subsubsection{Impactos Econômicos}

Os impactos econômicos são brutamente sentidos pelas sociedades que necessitam do turismo, por ele ser uma atividade econômica e socialmente ativa. Nos países em desenvolvimento, há um excelente grau de participação financeira nacional e internacional por meio do turismo, todo e qualquer investimento nesta área de rentabilidade econômica possui influência significativa e essa será refletida no desenvolvimento econômico e consequentemente social.

Para a O.M.T. (2001, p. 201), “[...] o turismo não só contribui com divisas, como, também, suaviza o problema do desemprego e, a longo prazo, pode fornecer um substituto das exportações tradicionais, cujo futuro é mais inseguro que o do turismo". Com esta afirmação é possível notar que a atividade turística pode ser mais rentável sócio-economicamente do que as demais atividades desenvolvidos no país que lhe levam divisas. No turismo é possível modificar seus valores sem tratados internacionais aumentando o benefício lucrativo de seus envolvidos.

Além disso, o turismo contribui para o Produto Interno Bruto - PIB -, influenciando as divisas do país. O nascimento do turismo em um lugar trás consigo a necessidade de fomento estrutural e a participação da iniciativa privada como investidora da atividade.

A geração de empregos é outro fator decisório na escolha e aplicação do turismo em uma região, são empregados indivíduos que possuem tanto a educação básica como superior, produzindo relevantes oportunidades dentro de uma comunidade, permitindo assim a sua valorização. Em conseqüência, o aumento e a distribuição de renda permitem um melhor desenvolvimento social local. 


\subsubsection{Impactos no Meio Ambiente}

Para Tulik "meio ambiente [...] não inclui apenas terra, ar, flora e fauna, mas engloba, também, o povo, suas criações e as condições sociais, econômicas e culturais que afetam suas vidas" (TULIK apud BARRETO, 1995, p. 118).

O meio o qual o indivíduo está inserido demonstra toda a sua evolução social, individual e sua necessidade financeira. Isso tomado de suas modificações não só físicas, mas sua consciência a cerca de dados assuntos, por exemplo, um local que vive da agricultura, sua região será de extensões de terra voltadas para o plantio, daí provêm os recursos financeiros.

Há diversos agentes que podem modificar o meio e um deles é o turismo, compondo esse o turista que é um agente totalmente transformador na localidade visitada. Este agente quando não possui consciência ambiental, sobre o que lhe circunda, acaba destruindo a localidade visitada sem perceber sua ação.

O empresário também possui atitudes que podem degradar o meio ambiente visitado, um exemplo citado pela O.M.T. (2001) é a poluição arquitetônica que consiste em construir um prédio fora das linhas de identidade local. Esta poluição pode diminuir os moradores em lugares com poucos recursos disponíveis para o turismo. O aumento do lixo e o tratamento indevido ou ausência do próprio é outro problema que a demanda turística ocasiona a comunidade receptora. Por vezes, esse material fica exposto em meio às avenidas degradando a visão paisagística local. A poluição sonora e do ar resultante do fluxo de automóveis advindos de outras regiões, a erosão devido a algumas atividades radicais e o desequilíbrio hídrico pode afetar negativa e diretamente os moradores e beneficiar os turistas.

Mathieson e Wall apud O.M.T. (2001, p. 233), comentam que: "é difícil determinar o grau de responsabilidade única do turismo na adoção e na expansão de medidas de conservação, ainda que seja evidente que a atividade turística exerça um papel muito importante". Com isso os impactos também podem ser positivos ao lugar. De acordo com a O.M.T. (2001), o turismo pode estabelecer melhorias ambientais e padrões de restauração e conservação para as mesmas, ao estimar a valorização do meio que lhe envolve.

Todos estes fatores exigem da administração pública iniciativas e planejamento turístico para um melhor e razoável fomento desta atividade, para Lea apud O.M.T. (2001, p. 234), “a expectativa de aumentar o número de visitantes contribui para aumentar os esforços para a conservação e o planejamento, especialmente quando a atividade turística é contemplada 
como uma atividade importante na geração de recursos e empregos", capturando para a comunidade os benefícios citados.

Portanto, os impactos turísticos são inúmeros, vão desde a economia até a sociedade, são de ordem positiva e negativa, tudo depende de como a sociedade observa o acontecimento e o transforma em benefício. A comunidade e o governo devem, ao programar o turismo em sua região, estar atenta a todos os acontecimentos para modificar o caminho deles caso lhe sejam maléficos, preservando assim todo o ambiente que lhe circunda, e proporcionando um desenvolvimento sustentável dos recursos que o turismo e os atingidos necessitam.

\subsubsection{Ministério do Turismo - Plano Nacional do Turismo e Estrutura Organizacional}

O turismo, no Brasil, assim como em diversas partes do mundo tornou-se uma importante atividade econômica nas últimas décadas. Visando a importância dela e sua abrangência social, o governo decide fundar, em 2003, o Ministério do Turismo (MTUR).

Assim,

[...] o Mtur foi instituído com a missão de promover o desenvolvimento do turismo como agente de transformação, fonte de riqueza econômica e de desenvolvimento social, por meio da qualidade e competitividade dos produtos turísticos, da ampliação e melhoria de sua infra estrutura e da promoção comercial do produto turístico brasileiro no mercado nacional e no exterior (PNT, 2007, p. 43).

Ou seja, o MTUR foi criado única e exclusivamente, com a função de fomentar, qualitativa e quantitativamente, o turismo interno para sua efetiva execução por mercados nacionais e internacionais.

Este órgão muniu-se de planos, macroprogramas e programas finalizando este desenvolvimento nacional turístico. Um dos resultados destes projetos é o Plano Nacional de Turismo (PNT), continuidade intelectual do Programa de Regionalização do Turismo existente em outro momento no País.

O Plano Nacional de Turismo é o instrumento que o Ministério possui de planejar e executar o turismo no País. Este método trouxe ao trade nacional uma melhor perspectiva do futuro turístico brasileiro, seja em sua infra-estrutura, seja em apoio àqueles que são a base para a

\footnotetext{
4 “Trade Turístico: Conjunto de empresas que operam turismo. Agências de viagem, operadoras de turismo, hotéis, restaurantes, transportadoras e todas as entidades que se envolvem com turismo" (VIERA et all, 2003, p.442).
} 
realização desta atividade. O plano 2007/2010, traz em sua ideologia central a inclusão por diversos meios, dentre eles a econômica e a social por meio de fomentos, programas, enfim por meio do desenvolvimento interno da oferta e da demanda (PNT, 2007). A partir destes princípios o turismo nacional possui visão, objetivos gerais e específicos como meios de alcance para suas metas de manutenção, fixação e principalmente fomento do turismo.

Por sua grandiosidade e diversidade o País tem como visão abordagens sobre diversidade e sustentabilidade, não só para manter o turismo mas, fundamentalmente, para um fortalecimentontinuidade da identidade brasileira em seus múltiplos e específicos pontos.

Nesta perspectiva, o Plano, em seus objetivos gerais, busca a efetividade desta visão para o País por ações de manutenção, aprimoramento e inclusão. Portanto, por seus objetivos específicos ele atinge a sociedade, seu cliente e objeto e, cumpre àqueles gerais. Dentre seus objetivos específicos é possível destacar algumas ações do PNT 2007/2010 (p.16),

Garantir a continuidade e o fortalecimento da Política Nacional o Turismo e da gestão descentralizada; [...]Ampliar e qualificar o mercado de trabalho nas diversas atividades que integram a cadeia produtiva do turismo; [...] Consolidar um sistema de informações turísticas que possibilite monitorar os impactos sociais, econômicos e ambientais da atividade, facilitando a tomada de decisões no setor e promovendo a utilização da tecnologia da informação como indutora de competitividade[...].

O Plano estabelece algumas metas para a sua concretização, são elas, "promover a realização de 217 milhões de viagens no mercado interno [...]; criar 1,7 milhão de novos empregos e ocupações [...]; estruturar 65 destinos turísticos com padrão de qualidade internacional [...]; gerar 7,7 bilhões de dólares em divisas [...]” (2007, p.48).

Para uma correta visualização dos acontecimentos, acompanhamento, e influencias no andamento do turismo brasileiro, o Ministério do Turismo (PNT, 2007, p. 43), “[...]implementou, como base da sua atuação, um modelo de gestão pública descentralizada e participativa, integrando as diversas instâncias da gestão pública e da iniciativa privada [...]”. Segundo o Ministério do Turismo,

A proposta de gestão descentralizada do Plano Nacional de Turismo vem fomentando a consolidação de uma rede de entidades e instituições, em todo o território nacional, envolvendo o poder público nas três esferas de governo, a iniciativa privada e o terceiro setor. Este universo de agentes relacionados ao turismo tem promovido a realização de diversos fóruns de discussão e deliberação sobre a Política Nacional de Turismo e seus desdobramentos territoriais no país (2006, p.30). 
Desta maneira, o modelo finaliza observar e gerir, de maneira macro e ao mesmo tempo específica e detalhada, os acontecimentos nas diversas escalas e lados do turismo. E ainda, desenvolver “[...] ambientes de reflexão, discussão e definição das diretrizes gerais para o desenvolvimento da atividade nas diversas escalas territoriais e de gestão do País [...]" (PNT, 2007, p. 43), para que nenhuma ação dentro do órgão esteja em descomunhão com a realidade turística brasileira.

Segundo o PNT (2007), a gestão nacional do turismo é formada por três órgãos: O MTUR, o Conselho Nacional de Turismo ${ }^{5}$ criado em 2006 e auxiliador do ministro na execução do PNT e dividido em 10 câmaras temáticas; e pelo Fórum Nacional de Secretários e dirigentes Estaduais de Turismo ${ }^{6}$ que indica as questões não solvidas e equação de situações vividas.

Assim, os fóruns, as redes de discussão surgidas permitem ao Ministério a observância da realidade brasileira no turismo, ainda, as deliberações e discussões a cerca dos assuntos comuns no contexto brasileiro trazem uma enorme troca de experiências entre os estados e em conseqüência o desenvolvimento amplificado do turismo.

Figura 2: Estrutura de Coordenação da Gestão Descentralizada.

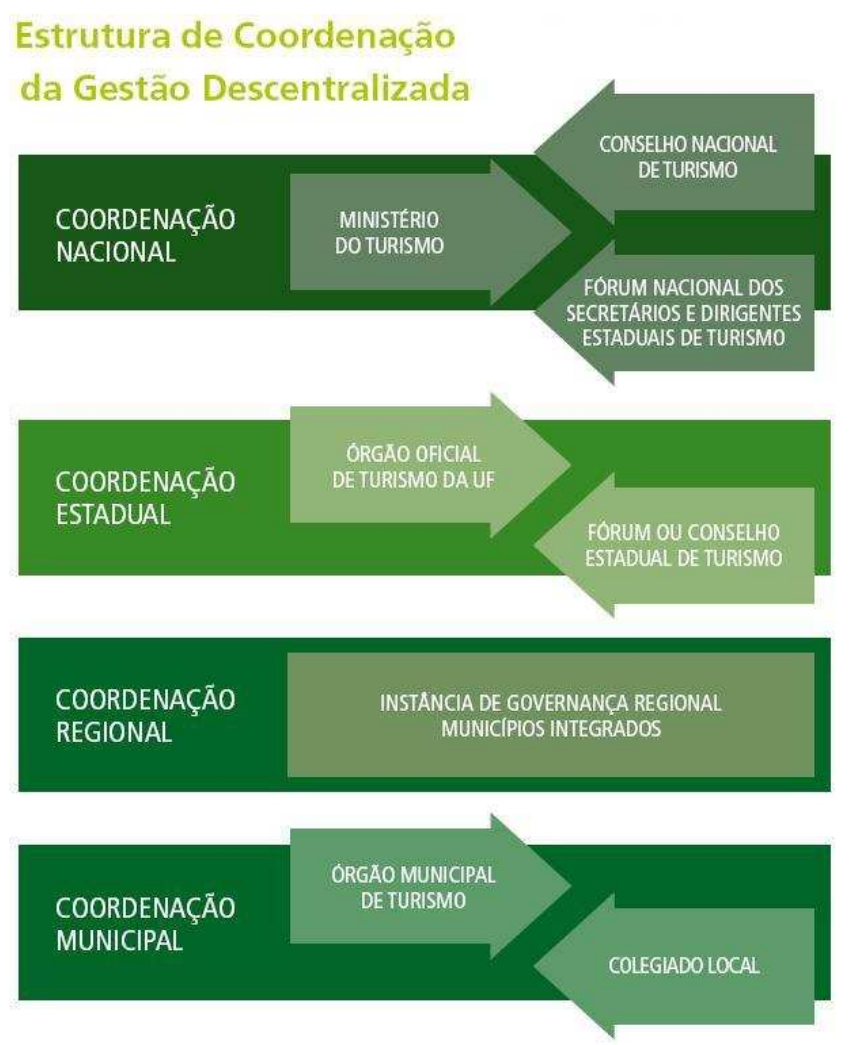

\footnotetext{
5 “ “...] Formado por representantes do governo federal e dos diversos segmentos do turismo. O conselho é hoje integrado por 65 conselheiros de instituições e entidades do setor em âmbito nacional" (PNT, 2007, p. 43).

6 “[...] órgão consultivo, constituído pelos secretários e dirigentes estaduais de turismo” (2007, p. 44).
} 
Fonte: Plano Nacional de Turismo 2007/2010. MTUR. 2007, p. 45.

A estrutura da coordenação permite uma visualização abrangente e setorial do alcance das discussões, assim como a cadeia atingida pelas trocas de experiências. De acordo com o Plano (2007), esta gestão descentralizada trás um produto das ações ministeriais no turismo setorial e nacional ao dispor os impactos desta atividade.

Figura 3: Gestão Descentralizada do Turismo.

Gestão Descentralizada do Turismo

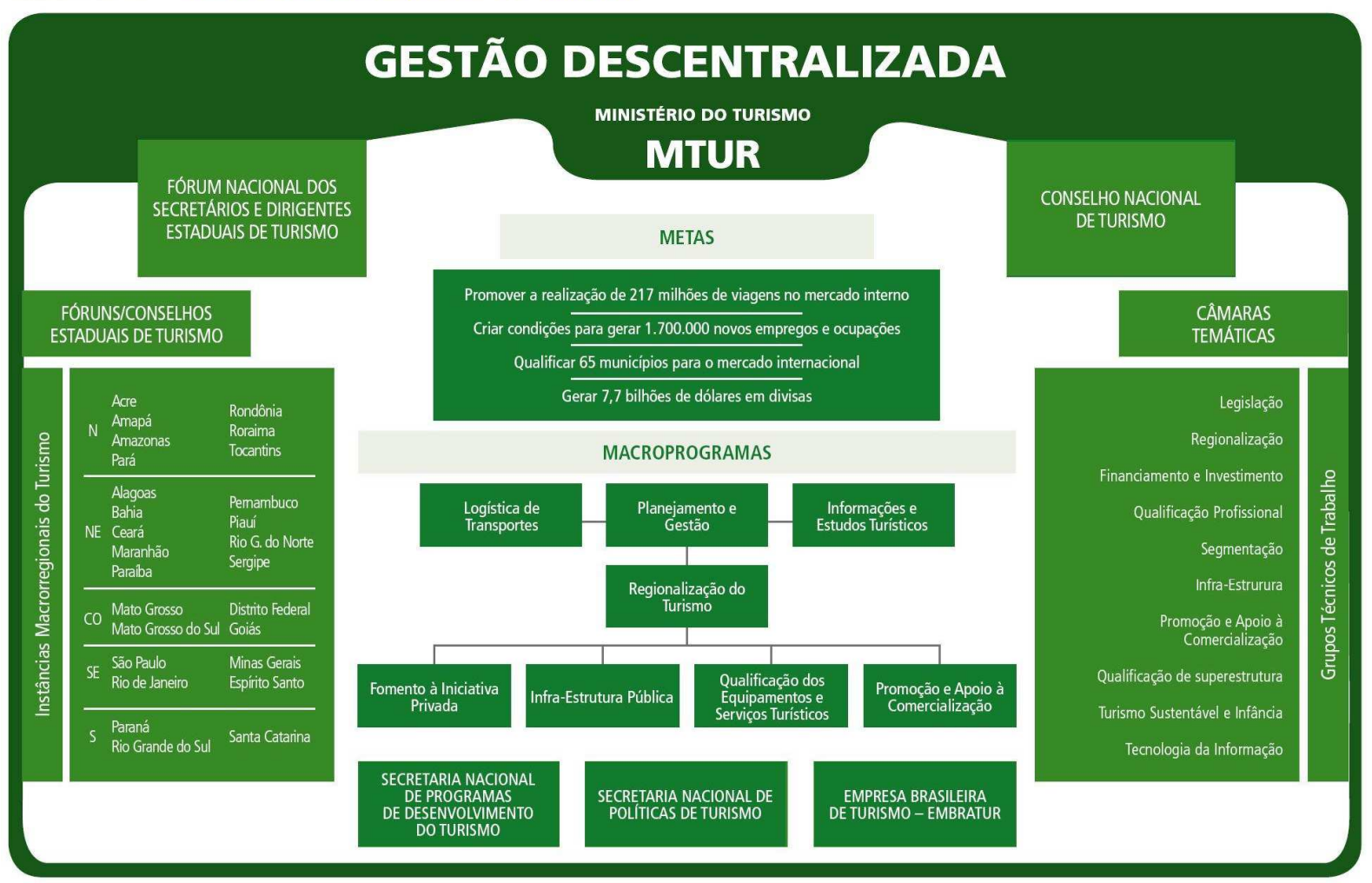

Fonte: Plano Nacional de Turismo 2007/2010. MTUR. 2007, p. 45.

Ao observar os quadros percebe-se a estrutura do Ministério do Turismo para propor, infundir ações e captar informações necessárias às tomadas de decisão deste órgão. Ainda é possível visualizar o alcance e a troca de informações e vivências entre estados e câmaras temáticas, necessários ao turismo nacional.

O ambiente organizacional do Ministério do Turismo divide-se em, Consultoria Jurídica, Gabinete do Ministro, Secretaria Executiva, Secretaria Nacional de Políticas de Turismo, 
Secretaria Nacional de Desenvolvimento do Turismo e Embratur ${ }^{7}$. Conforme explicita a figura abaixo,

Figura 4: Estrutura Organizacional do Ministério do Turismo.

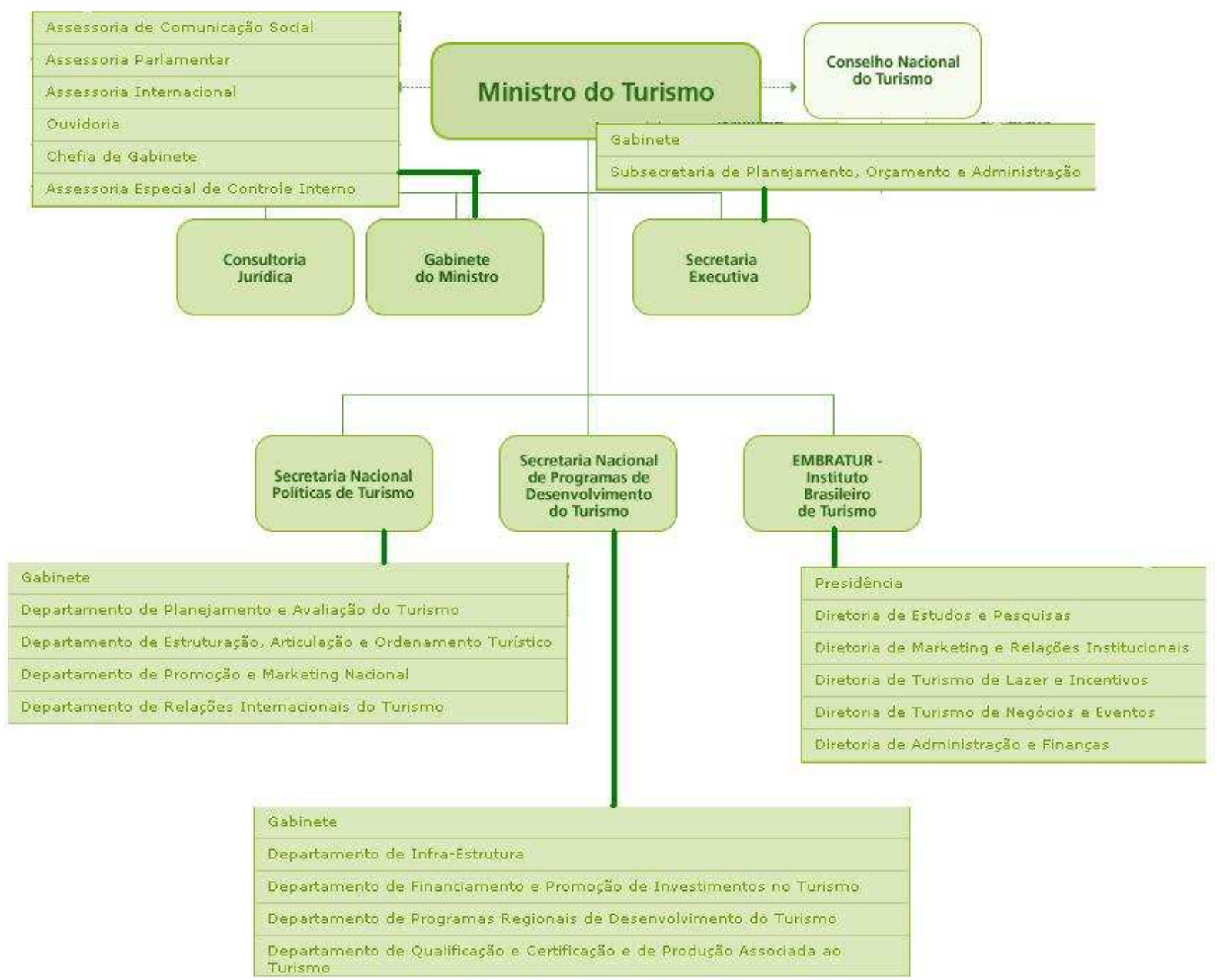

Fonte: Estrutura do Ministério do Turismo, disponível em www.turismo.gov.br, acesso dia $09 / 05 / 2009$.

O Conselho e o Fórum são de caráter consultivo somente, sendo que suas atividades não incidem nas decisões e ações diretas do Ministério.

O MTUR expõe a existência do Gabinete do Ministro que tem a função de representá-lo,

\footnotetext{
${ }^{7}$ Instituto Brasileiro de Turismo.
} 
[...] política e social, ocupa-se das relações públicas e se dedica ao preparo e despacho do seu expediente pessoal [...] promove a articulação entre o Ministério e os órgãos que compõem a Presidência da República e exerce outras competências que lhe forem atribuídas pelo Ministro de Estado (2009).

Para dar o suporte necessário ao Ministro em suas atividades cotidianas e extraordinárias. Ele é subsetorizado em assessoria de Comunicação Social ${ }^{8}$; assessoria Parlamentar ${ }^{9}$; assessoria Internacional $^{10}$; assessoria Especial de Controle Interno ${ }^{11}$; Ouvidoria ${ }^{12}$; e Chefia de Gabinete $^{13}$.

A Secretaria Executiva é composta de dois sub-órgãos o gabinete ${ }^{14}$ e a subsecretaria de planejamento, orçamento e administração ${ }^{15}$. O MTUR expõe que esta secretaria,

Auxilia o Ministro de Estado na definição de diretrizes e políticas no âmbito da Política Nacional de Turismo em observância às diretrizes propostas pelo Conselho Nacional de Turismo. Supervisiona e coordena as atividades das Secretarias integrantes da estrutura do Ministério do Turismo e da autarquia vinculada - Embratur, além de exercer o papel de órgão setorial dos Sistemas de Governo Federal (planejamento e orçamento, programação financeira, contabilidade federal, modernização administrativa, recursos humanos, recursos logísticos, informação e informática) (2009).

De certa maneira, a Secretaria Executiva é o órgão mantenedor das atividades de alta gestão no Ministério. Portanto, ela tem por atividades, zelar pela efetividade e qualidade dos serviços do Ministério assim como dos órgãos a ele vinculado.

A Secretaria Nacional de Políticas de Turismo possui por missão, de acordo com o Ministério (2009), "executar a política nacional para o setor, orientada pelas diretrizes do Conselho Nacional do Turismo. É responsável pela promoção interna e zela pela qualidade da prestação do serviço turístico brasileiro".

Ainda conforme o PNT (2007, p. 43), a esta Secretaria é atribuído "formular, elaborar, avaliar e monitorar a Política Nacional do Turismo, de acordo com as diretrizes propostas pelo Conselho Nacional de Turismo, bem como articular as relações institucionais e internacionais necessárias para a condução dessa Política”. Desta maneira, este setor está intimamente ligado

\footnotetext{
${ }^{8}$ Competências em anexo.

${ }^{9}$ Competências em anexo.

${ }^{10}$ Competências em anexo.

${ }^{11}$ Competências indisponíveis.

${ }^{12}$ Competências em anexo.

${ }^{13}$ Competências indisponíveis.

${ }^{14}$ Competências em anexo.

${ }^{15}$ Competências em anexo.
} 
aos procedimentos no Ministério envolvidos com a política interna e externa assim como seu fomento nos ambientes inseridos e com as empresas aí contidas.

A Secretaria de Políticas é composta pelo Departamento de Planejamento e Avaliação do Turismo $^{16}$; de estruturação, articulação e ordenamento turístico ${ }^{17}$; de promoção e marketing nacional $^{18}$; e de relações internacionais do turismo ${ }^{19}$.

Quanto à Secretaria Nacional de Programas de Desenvolvimento do Turismo, seu papel é "promover o desenvolvimento da infra-estrutura e a melhoria da qualidade dos serviços prestados ao turismo" (MTUR, 2009).

O PNT (2007, p.43) expõe ainda que, à essa "compete realizar ações de estímulo às iniciativas públicas e privadas de fomento, de promoção de investimento em articulação com os PRODETUR, bem como apoiar e promover a produção e comercialização de produtos associados ao turismo e a qualificação dos serviços". Portanto, esta segunda Secretaria tem por missão ser o elo entre a idealização do turismo e a execução deste, através dos incentivos para a utilização dos meios cabíveis de incentivo e financiamento voltados a atividade turística nacional.

Ela é dividida nos departamentos de Infraestrutura Turística ${ }^{20}$; de Programas Regionais de Desenvolvimento do Turismo ${ }^{21}$; de Financiamento e Promoção de Investimentos no Turismo $^{22}$; e de Qualificação, Certificação e Produção Associada ao Turismo ${ }^{23}$.

Por fim, à Embratur, que é uma autarquia federal, compete "a promoção, no marketing e apoio à comercialização dos produtos, serviços e destinos turísticos do País no exterior" (PNT, 2007, P. 43). À Embratur coube a divulgação dos produtos turísticos brasileiros no exterior, e por conseqüência a atração, ao Brasil, de novos turistas estrangeiros.

Esta setorização das atribuições do Ministério, para almejar as metas e as expectativas do turismo nacional, permite um melhor cumprimento das metas do Plano Nacional de Turismo. A estrutura organizacional do Ministério é de grande alcance e permite idealizar e incentivar as realizações no trade para investimento e crescimento do turismo nacional, assim como o

\footnotetext{
${ }^{16}$ Competências em anexo.

${ }^{17}$ Competências em anexo.

${ }^{18}$ Competências em anexo.

${ }^{19}$ Competências em anexo.

${ }^{20}$ Competências em anexo.

${ }^{21}$ Competências em anexo.

${ }^{22}$ Competências em anexo.

${ }^{23}$ Competências em anexo.
} 
aumento do número de turistas estrangeiros ao País e o fortalecimento da imagem do Brasil no exterior.

A partir dessa estrutura organizacional é possível perceber que o MTUR, de fato, desenvolve e idealiza o turismo brasileiro em três esferas, pelas Secretarias Nacionais e pela Embratur, em políticas, programas e marketing externo e interno.

A partir de uma série de perspectivas, no total até junho de 2006, foram elaboradas 215 propostas para o desenvolvimento do turismo entre os anos 2007 e 2010. Sendo elas: 42 no eixo planejamento e gestão, 9 em logística e transportes, 11 em infra-estrutura, 42 em qualificação, 24 em informação, 22 em estruturação e diversificação da oferta, 25 para o fomento e 40 em promoção, marketing e apoio à comercialização (MTUR, 2006).

O Ministério do Turismo estabeleceu, para o cumprimento de seus objetivos e propostas, o método "de adição de valor e estabelecendo-se uma relação de causa e efeito entre as perspectivas estratégicas do turismo [...]" (MTUR, 2006, p. 109). Esta metodologia é dividida em quatro elementos, o primeiro, resultados institucionais, segundo o MTUR (2006, p.109) "compreendem os elementos estratégicos do topo da cadeia de adição de valor do Ministério do Turismo", estes elementos são, emprego e renda, desenvolvimento sustentável e divisas.

O segundo, resultados operacionais (impactos) "são aqueles elementos que medem os impactos das atividades desenvolvidas pelo Ministério do Turismo" (MTUR, 2006, p.109), este por sua vez é preenchido pelo volume nacional, internacional e qualidade do produto turístico.

O terceiro, atividades, este grupo "categoriza e agrupa as propostas de ação que irão impactar os resultados operacionais", conforme o MTUR (2006, p.109). Este é estruturado pela promoção, marketing e apoio à comercialização, fomento e estruturação e diversificação da oferta.

E o quarto, suporte. Ele é integrado pela infra-estrutura, logística de transportes, qualificação, informação e planejamento e gestão. Esta por sua vez, "categoriza e agrupa as propostas de ação que darão suporte e sustentabilidade às atividades" (MTUR, 2006, p. 109). Esta metodologia é configurada e desenhada conforme figura abaixo.

Figura 5: Mapa de Adição de Valor. 


\section{MAPA DE ADICĀO DE VALOR}

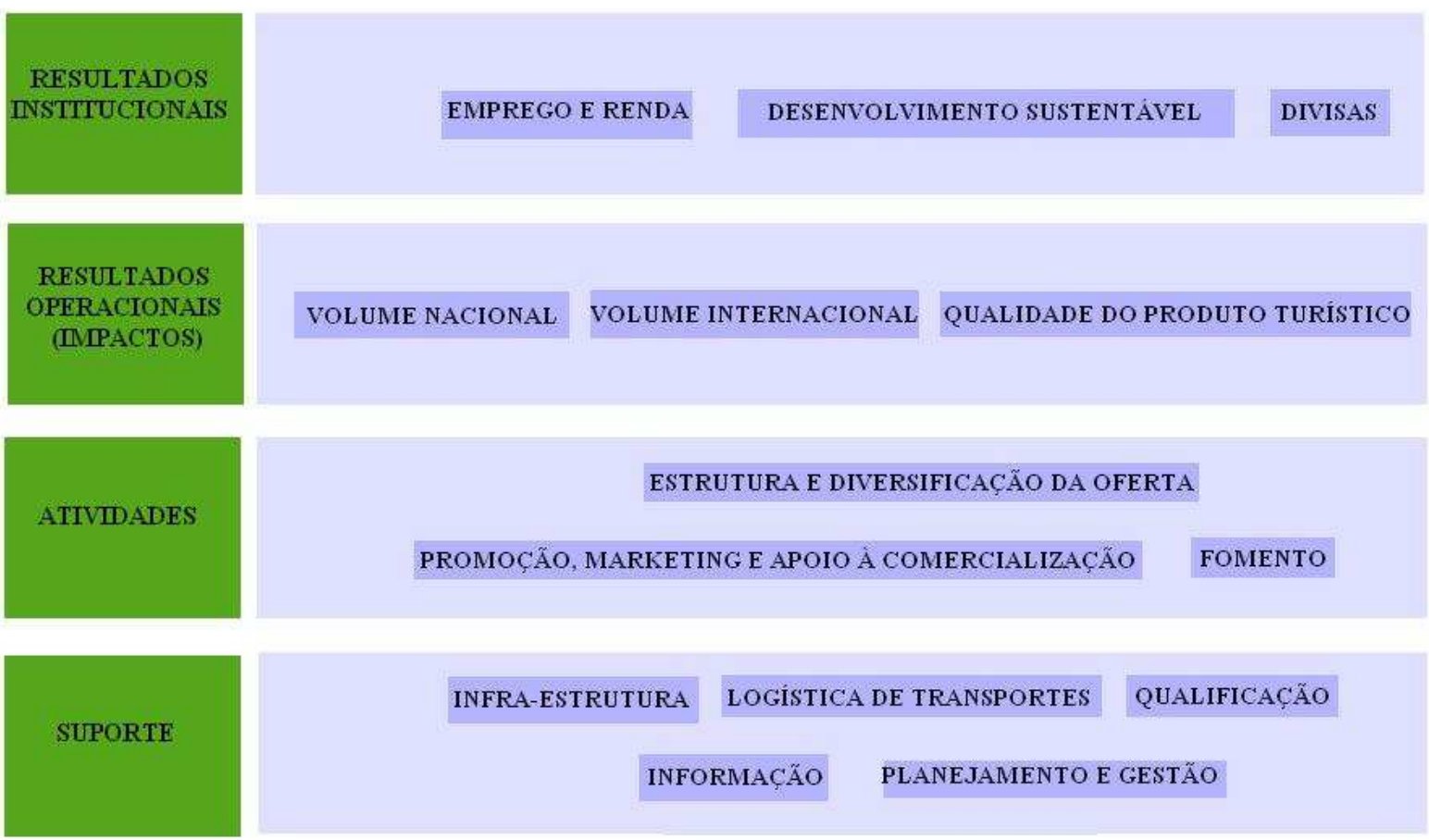

Fonte: MTUR, 2006, p.109.

Este modelo de gestão interconecta seus sub-elementos no instante que os subsídios presentes nas atividades e no suporte, individualmente, se relacionam com cada um daqueles constantes nos resultados institucionais e operacionais. Desta maneira as expectativas do Ministério são pautadas e executadas, tendo por base o Plano Nacional de Turismo, a competência de cada área e o relacionamento em adição de valor.

Apesar de toda a estrutura apresentada, o Ministério, pelo PNT (2007), aponta desafios para os anos que seguem o plano dentre eles a concepção de novos paradigmas aos agentes do turismo à compreensão da consecução da atividade, além da privação de infra-estrutura generalizada.

\subsection{Qualidade}

\subsubsection{História da Gestão pela Qualidade}

Os seres humanos procuram, buscam a qualidade há alguns séculos. Na China, segundo Algarte et all (2000) os fabricantes de produtos artesanais zelavam a todo o momento pela qualidade, além disso, existiam regras sobre a fabricação e a manutenção da qualidade feitas 
pelo Estado. Os produtos tinham garantia, aqueles falsificados ou não identificados eram retirados do comércio, por fim os produtores deviam gravar seu nome em seus artigos sendo, o fabricante punido caso não houvesse seguimento dos padrões. Os produtos eram avaliados e esta gravação nos produtos permitiu a rastreabilidade dos responsáveis por tais produtos.

O mesmo autor coloca que a metrologia permitiu a padronização de diversos utensílios que foram refletidos nas construções, não só da China como de outros impérios. Egito, Pérsia e Grécia também utilizaram como controle de processos a normalização dos aparelhos a serem utilizados em sua arquitetura. Algarte et all expõe, sobre o controle de processos como exigência à qualidade, que

o controle de processos é muito mais antigo e mais abrangente que o controle estatístico da qualidade [...]os primeiros controles quase não usavam os métodos estatísticos com exceção de alguns dados descritivos. A essência do antigo controle de processo consistia em métodos uniformes, normas de procedimentos e obediência às normas [...] (2000, p. 20)

Sendo assim, o controle de processos surgiu há muitos anos e foi este controle que permitiu a grandiosidade da arquitetura destes países. Não havia ainda métodos matemáticos de inspeção de qualidade, porém, a minuciosidade na normalização dos métodos e resultados consagraram o sucesso destes países. Algarte et all confirma esta exposição ao considerar que,

o verdadeiro sucesso dos antigos construtores, que seguiam sempre o mesmo conjunto de normas, deve-se ao uso de materiais, métodos e procedimentos uniformes [...] O controle de processo permitiu a precisão das medições [...] somente um sistema de controle de processo bem desenvolvido poderia fornecer produtos com tal precisão (2000, p.22).

A Idade Média foi marcada pela manufatura, sendo que esta permitia a visualização do andamento do produto pelo artesão. Algarte et all considera que "desde que começou a manufaturar produtos para o seu próprio uso e para o uso de seus familiares, o homem controlava todo o processo de artesanato, concepção, projeto, escolha da matéria prima, fabricação e controle da qualidade" (2000, p. 24). Assim, desde sua concepção até a pósvenda era realizada pelo produtor, esta presença incondicional do feitor permitia que o mesmo primasse a todo instante pela qualidade uma vez que a ausência da qualidade diminuía suas produção diretamente.

Ainda segundo este autor, o aumento na quantidade demandada ao passar dos anos fez com que o artesão dividisse a sua ciência com aprendizes. Isso, dividiu o trabalho executado em etapas, porém, seu conhecimento, ferramentas e matéria prima era de gerenciamento e 
propriedade do artesão, patrão. Com o passar dos séculos e com o surgir da Revolução Industrial o trabalho passou a ser subdivido e o capital intelectual de um labor era de propriedade da indústria.

Neste instante, a qualidade era prezada por supervisão, agentes eram destinados nas indústrias com o objetivo exclusivo de verificar a qualidade dos produtos fabricados. Com o crescimento da industrialização e do mercado de consumo, as relações consumidor e produtor foram distanciadas de maneira que já não havia retorno do cliente com relação ao produto adquirido ao fabricante (ALGARTE et all, 2000).

No início do século XX, surgem as produções em massa. Para dar conta da quantidade de pedidos encomendados, a setorização do trabalho foi fundamental para o escoamento rápido da produção. Com isso a inspeção de qualidade por amostragem surgiu como resultado deste fenômeno.

$\mathrm{Na} 1^{\mathrm{a}}$ Guerra Mundial, surge a necessidade de um armamento de segurança para as batalhas. Neste período, a indústria continha somente a inspeção como forma de controle da qualidade. Porém as grandes quantidades produzidas não favoreciam a qualidade dos produtos e a necessidade de $100 \%$ de produtos vistoriados tornavam o serviço de qualidade em um problema na produção, pois o custo era alto (ALGARTE et all, 2000).

Para Algarte et all, em 1930, o controle estatístico emergiu tratando da qualidade por amostras, fazendo com que os fenômenos fossem diagnosticados nas etapas de produção, a inspeção verificava o resultado do processo de produção e era utilizada como prevenção a qualidade nas matérias utilizadas.

Algarte et all (2000, p. 33) comenta que,

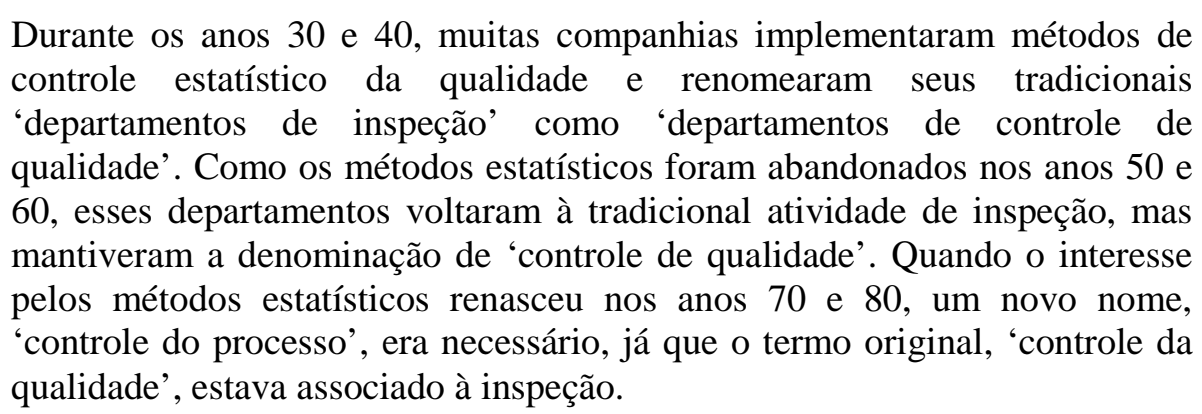

De acordo com este autor, a segunda Guerra Mundial foi decisória na mudança de pensar da sociedade com relação aos produtos, após a Grande Depressão e a carência de produtos no 
mercado fez com que os indivíduos solicitassem produtos de maior durabilidade e qualidade. Isto modificou a postura da indústria como executora destes produtos.

O ambiente da qualidade começa a mudar nos anos 60. Os norte-americanos iniciam programas de motivação para a qualidade total e logo em seguida surge o círculo de controle de qualidade dos japoneses. Este círculo apresenta ao mundo uma nova concepção do tema qualidade, pois, ele não visava somente o final, mas todo o contexto que o produto esta incluso (ALGARTE et all, 2000).

O período da Guerra Fria trouxe uma nova abordagem a ser trabalhada para a qualidade, segundo Algarte et all (2000, p.35),

[...] estudos mostravam que os problemas da falta de qualidade eram causados em $80 \%$ dos casos por falhas gerenciais e não por falhas técnicas. As empresas sempre se preocuparam com a qualidade no 'chão-de-fábrica', esquecendo-se que os grandes problemas surgiam das falhas de comunicação entre os diversos níveis hierárquicos.

Isto fez com que a indústria se realinhasse a partir de programas de Garantia de Qualidade, Algarte et all afirma que "[...] a Garantia da Qualidade resultou da aplicação conjunta da teoria de sistemas e dos princípios do Controle Total da Qualidade” (2000, p. 36). Esta abordagem da qualidade foi melhorada e, portanto necessária para a aplicação em diversos setores da economia.

Esta reestruturação surgiu de exigências norte-americanas e de seus organismos visando a qualificação da alta gerência assim como do produto final da organização, Algarte et all expõe que, porém, “[...] a adoção de programas formais de garantia da qualidade nos Estados Unidos decorreu mais por imposições legais do que por razões de mercado" (2000, p. 37). A sistemática processual é precisa, porém sua aplicação também e este não cumprimento de regras inviabilizam o crescimento empírico sobre a qualidade.

Em 1961, Feigenbaum lança o livro Total Quality Control Engineering and Management, defendendo a teoria do Controle de Qualidade Total, conforme Algarte et all,

[...] que envolve de maneira sistêmica todos os órgãos de empresa, passando pelo marketing, projeto, desenvolvimento, aquisição, fabricação, inspeção e testes, expedição, instalação e assistência técnica. No Controle Total da Qualidade, a ênfase é no planejamento de todas as etapas de produção, incluindo os fornecedores, adotando-se medidas preventivas tanto na administração como na produção (2000, p. 38). 
Desta forma, a partir do planejamento e da prevenção de situações é possível munir-se contra possíveis erros e manter-se em um patamar razoável de qualidade. A teoria de Feigenbaum revolucionou a percepção da qualidade como sendo um produto voltado ao cliente, relacionando a postura dos envolvidos e tratando a qualidade como sendo efeito de um sistema completo (ALGARTE et all, 2000).

No Japão, prevaleciam até a década de 60, a má qualidade dos produtos e os péssimos resultados. Com a ocupação norte-americana neste país foi percebida a necessidade da gestão pela qualidade, William Edwards Deming e Joseph M. Juran foram enviados ao País para trabalharem em cima do quesito qualidade, eles juntamente com Kauru Ishikawa desenvolveram os Círculos de Controle de Qualidade, que em 1962 foi difundido pelo mundo com resultados positivos (ALGARTE et all, 2000).

Algarte et all defende que a qualidade japonesa evoluiu graças à observância a três quesitos, "garantia da qualidade orientada para a inspeção [...] para o controle do processo [...] durante o desenvolvimento do produto [...]" (2000, p. 41). Estas três bases foram o impulso para o modelo japonês alcançar a qualidade em totalidades em seus produtos. Algarte coloca que estes pontos não foram as únicas variáveis para o sucesso japonês, ele afirma que

o modelo japonês de desenvolvimento do Controle da Qualidade alcançou maior sucesso que o modelo americano e ocidental em função de fatores culturais e religiosos, modo de organização dos sindicatos, sistema de remuneração dos trabalhadores, relação entre fabricantes e montadoras, incentivos do governo, etc. (ALGARTE et all, 2000, p. 42)

Ou seja, a cultura envolvida foi imprescindível para a obtenção da qualidade no Japão.

Algarte et all (2000) defende que a globalização trouxe novas perspectivas ao ambiente de qualidade mundial. Com a abertura do comércio foi necessária a instituição de normas padrão para que todos andassem em um par de igualdade em qualidade. Desta maneira, a International Organization for Standartization (ISO) ganha espaço assim como suas normas de qualidade em diversas áreas e demandas. Algarte et all defende que,

A certificação de sistemas da qualidade difere da certificação de produtos. Enquanto a certificação de sistemas é o resultado da verificação da conformidade aos requisitos e procedimentos de gestão das normas, a certificação de produtos atesta o atendimento das características específicas de um produto (2000, p. 44).

Assim, o efeito das normas ISO é de certificar a qualidade do sistema, não somente o fim, mas principalmente o meio o qual é produzido o serviço ou produto, resultando em uma 
gestão total da qualidade. Algarte et all ainda coloca que, "o objetivo principal das normas de sistema da qualidade é disciplinar os sistemas organizacionais e gerenciais, a partir dos quais produtos e serviços são concebidos, projetados, fabricados e comercializados" (2000, p. 44), assim sendo a certificação de qualidade visualiza o sistema como objeto da ação e dos resultados qualitativos em uma organização.

As normas ISO são um grande passo para diversos países. Como resultado de normas a serem seguidas surgem pouco a pouco as premiações para aquelas entidades que cumprem a regra e são modelo a outras (ALGARTE et all, 2000).

No Brasil, a preocupação com a qualidade começou com as montadoras de automóveis e apontou majoritariamente no governo Vargas, com a Companhia Siderúrgica Nacional (CSN) e a Petróleo Brasileiro S. A. (Petrobras) por necessitarem evitar acidentes e danos aos envolvidos na produção.

Algarte et all expõe que "na área de bens de consumo, a preocupação com a qualidade surgiu com a necessidade de melhorar a produtividade e aumentar a competitividade das empresas" (2000, p. 55), isso por causa da abertura comercial e a grande competitividade de outras entidades no País, desta forma quem não melhorasse acabava quebrando e fechando as portas.

Em 1921, o governo ao se preocupar com "metrologia, normalização e qualidade" (ALGARTE et all, 2000, p. 56) criou a Estação Experimental de Combustíveis e Minérios e o Laboratório de Ensaios de Materiais da Escola Politécnica de Engenharia, logo em seguida no ano 1927, surgiu a Associação Brasileira de Ensaio de Matérias “[...] cujos objetivos eram aperfeiçoar e verificar os métodos de ensaios utilizados nos laboratórios do País. Essa Associação veio a constituir-se no embrião do processo de normalização nacional do Brasil" (ALGARTE et all, 2000, p. 56).

As duas primeiras entidades serviram de embasamento para a criação de outros dois órgãos mais tarde, em 1933, o Instituto Nacional de Tecnologia (INT) e o Instituto de Pesquisas Tecnológicas (IPT), “[...] ambas as instituições dedicavam-se a atividades muito mais amplas do que a simples análise de materiais, inclusive desenvolvendo ações pioneiras em metrologia" (ALGARTE et all, 2000, p. 57). O fomento de tais órgãos expõe a preocupação do Brasil neste período em gerir a qualidade nacional por parte do Estado.

Conforme Algarte et all (2000), em 1940 emerge no cenário brasileiro a Associação Brasileira de Normas Técnicas (ABNT), expondo a influência de cientistas no Estado. Na década de 60, a preocupação com a normalização foi exposta com a Divisão de Metrologia e a Comissão de 
Metrologia constantes no Instituto Nacional de Pesos e Medidas. Ainda nesta década foi instituído pelo governo o cumprimento às regras da ABNT.

Em 1970, surge o Sistema Nacional de Metrologia, Normalização e Qualidade (SINMETRO), tendo como órgãos o Conselho Nacional de Metrologia, Normalização e Qualidade Industrial (CONMETRO) e o Instituto Nacional de Metrologia, Normalização e Qualidade Industrial (INMETRO), em seu corpo gestor e executor de normas oficiais (ALGARTE et all, 2000).

A criação de tantos órgãos federais ao longo dos anos demonstra a preocupação do governo em desenvolver a qualidade e a padronização desta no âmbito nacional industrial.

Segundo Algarte et all (2000), a abertura comercial nas décadas de 70 e 80 expôs o País a competitividade internacional em qualidade e a ausência de tecnologias em comparação a potências mundiais em produtos.

Ainda segundo Algarte et all, em 1980 inicia o Programa da Qualidade e Produtividade (ProQP), este programa surgiu com o objetivo de "[...] promover a qualidade, aumentar a produtividade, reduzir custos e incrementar a competitividade de produtos e serviços brasileiros" (ALGARTE et all, 2000, p. 65). Este Programa era disposto em vários subprogramas, dentre eles, o de Articulação com o Setor Governamental que visava a "promoção da qualidade e produtividade na gestão empresarial" (ALGARTE et all, 2000, p. $65)$.

Em 1990 (ALGARTE et all, 2000), na Política Industrial e de Comércio Exterior (PICE), começa o Programa Brasileiro de Qualidade e Produtividade (PBQP), o Sistema Brasileiro de Certificação (SBC) e em consequiência o Prêmio Nacional de Qualidade (PNQ).

Algarte et all coloca que a gestão da qualidade emergiu de duas vias no Brasil, "a preocupação com defeitos e falhas de componentes [...]; controle de processos através de métodos estatísticos [...]; sistemas de garantia da qualidade [...]" e do "foco na satisfação do cliente [...]; modelos sistêmicos; programas motivacionais; gestão pela qualidade total; prêmio de excelência." (2000, p. 78). Este pensamento demonstra a evolução da filosofia à qualidade brasileira, ela começa com a racionalização de métodos, passa pela sistematização de responsabilidades e termina no reconhecimento da qualidade nas entidades brasileiras de qualquer ambiente, seja ele privado ou público.

Lima denota que o PBQP, tinha por fins "[...] sensibilizar e mobilizar o setor produtivos nacional para o desafio de um mundo em mudança, mais competitivo e mais exigente" (2007, p. 31). 
Dentro deste programa como no anterior havia uma abordagem para a administração pública que segundo Lima, "o foco da qualidade na administração pública nesse período foi na mobilização dos servidores e na análise e melhoria de processos, com o uso intensivo das ferramentas de qualidade" (LIMA, 2007, p. 32). Segundo este mesmo autor os métodos foram ineficazes não trazendo a mudança necessária à administração pública brasileira.

Neste Programa houve algumas modificações, entre elas a de 1995, que visava a gerência com ênfase na desburocratização e voltada ao cidadão, porém, esta reforma foi um reflexo de mudanças realizadas em outros países e tornou a administração pública mais cheia regras formais que gerenciais e práticas (LIMA, 2007).

Nesta época, o Subprograma Qualidade na Administração Pública foi modificado e se chamou Programa da Qualidade e Participação na Administração Pública (QPAP). De acordo com Lima, "o desafio dessa nova fase do Programa era torná-lo, efetivamente, um instrumento de transformação da gestão pública, orientando-a para resultados e para o cidadão" (2007, p. 36). Esta fase do programa modificou a maneira de filosofar da administração pública, ela expunha aos envolvidos a necessidade de desenvolvimento da organização pública como tal no sistema de gestão. Lima (2007) afirma que os fins eram claros, porém os meios para obtêlos não. Segundo o mesmo autor, o entendimento da necessidade de saída dos métodos de processo, porém não seu esquecimento, começou a ser utilizado o modelo de gestão do setor privado.

Em 1997, é idealizado Prêmio Nacional de Qualidade, nele o primeiro tópico para a Administração Pública. Até o ano de 2007, nenhuma organização pública foi agraciada com tal premiação. Ainda em 97, o Programa da Qualidade e Participação na Administração Pública passa por outra estruturação e volta-se para a gestão organizacional com foco no cliente externo, o cidadão (LIMA, 2007).

Em 2000, emerge no cenário nacional o Plano Nacional de Desburocratização (PND) que impactou, mas não trouxe resultados diretos à administração pública brasileira (LIMA, 2007). Este Plano e suas ações foram trabalhadas nos anos seguintes e, a partir de algumas mutações ele trouxe benefício.

\subsubsection{Programa Nacional de Gestão Pública e Desburocratização (GESPÚBLICA)}

Após diversos altos e baixos em normas, decretos, programas e ações, a partir do Decreto $\mathrm{n}^{\mathrm{o}}$. 5.378, de 23 de fevereiro de 2005, surge o Programa Nacional de Gestão Pública e 
Desburocratização (GesPública), originado a partir da reflexão, análise e fusão dos programas anteriores, como o Programa da Qualidade e Participação na Administração (QPAP) e o Programa da Qualidade no Serviço Público (PQSP). Ao realizar tais ações, o programa “[...] mantém-se fiel à finalidade de contribuir para a melhoria da qualidade dos serviços públicos prestados aos cidadãos e para o aumento da competitividade do País mediante melhoria contínua da gestão" (MPOG; SEGES, 2009, p. 07). Isto significa que mesmo com o decorrer dos anos, a ideologia de simplificação de trabalhos e otimização de resultados, pensada anteriormente pelos governos brasileiros em outros momentos da história nacional, foi conservada no Programa.

Assim, aponta Lima, sobre a competência do GesPública ao ser instituído como programa de melhoria do serviço público, "assume, assim, o GesPública, os contornos de uma política pública federativa maior, porque se trata da gestão em sua concepção essencial e pura, ou seja, independente do objeto gerado" (2007, p.39). Desta maneira, o Programa surge com o desafio de englobar todas as esferas do setor público e incentivá-las a verdadeiramente filosofar e agir nos padrões de qualidade na execução de seus serviços.

Por isto, coloca o Ministério do Planejamento e a Secretaria de Gestão no âmbito da administração federal, "não basta oferecer serviços de qualidade, é preciso atentar para as mais variadas dimensões da cidadania: o exercício dos direitos sociais e individuais; a liberdade; a segurança; o bem-estar; o desenvolvimento; a igualdade e a justiça" (2009, p. 08). O que demonstra a percepção destes órgãos, de grande influência nacional, da necessidade de buscar em suas ações a qualidade total, focalizar a excelência e ir ao encontro da população e suas necessidades, além do estabelecimento do Programa como um dos meios para atingir estes objetivos.

O Ministério do Planejamento e a Secretaria de Gestão (2009, p. 15) defendem que, “a compreensão de que um dos maiores desafios do setor público brasileiro é de natureza gerencial fez com que se buscasse um modelo de excelência em gestão focado em resultados e orientado para o cidadão". Este modelo de excelência serve de base ao GesPública e situa o cidadão em uma posição de agente regulador e sofredor dos serviços e produtos públicos.

Isto é explicitado quando no documento de referência do Programa, estes órgãos colocam o GesPública como “[...] um poderoso instrumento de cidadania, conduzindo cidadãos e agentes públicos ao exercício prático de uma administração pública ética, participativa, descentralizada, promotora do controle social e orientada para resultados, entre outras ações gerenciais" (2009, p. 09). Ou seja, este instrumento além de ser voltado ao cidadão, cliente, 
permite e espera deste, a demanda de suas necessidades e interpelações como forma de equilibrar e traçar ao longo do tempo a qualidade máxima possível em serviços públicos.

Lima expõe, da base do Programa e envolvimento cidadão que, "a proposta do GesPública está fortemente alicerçada nos princípios da administração gerencial (managerialism), cuja essência é orientar a administração pública para resultados e para o cidadão [...]” (2007, p. 198).

Em suma, não adianta que a administração pública trabalhe, ela deve executar seu labor visando as idéias centrais de ser poder público, ser voltado a este e alcançar o bem comum; realizar o expresso em leis; executar suas tarefas sem diferenciação de indivíduos na sociedade; dentre outros.

Lima afirma,

O envolvimento do cidadão e da sociedade como controladores da gestão pública, além de ser da natureza do Estado democrático pleno, visto que pratica uma democracia espontânea e contínua, é o principal fator de sustentação da gestão pela qualidade, pois passa a ser exigido de fora de sustentação da gestão pela qualidade, pois passa a ser exigido de fora para dentro da organização, independentemente de suas descontinuidades administrativas internas (2007, p. 164).

Ou seja, o engajamento do cidadão não é por mera participação mas, sua dedicação nos assuntos do Programa traz benefícios no que diz respeito ao encontro à qualidade e percepção externa da organização pública e dos departamentos existentes. Lima (2007) coloca, ainda que, a ausência desta participação pública torna as atitudes e assertivas voltadas para a excelência em mera coincidência de administradores e gestores.

O Programa Nacional de Gestão Pública e Desburocratização não funciona somente com a cobrança da sociedade, ele também possui diversos ambientes para respeitar e seguir para efetivar suas ações na sociedade. Os primeiros deles são os princípios constitucionais, constantes no artigo 37 da Constituição Federal de 1988, (impessoalidade, legalidade, moralidade, publicidade e eficiência), os significados, as características e os objetivos da administração pública, pois, estes não são os mesmos das instituições privadas, embora a excelência seja procurada por ambas. 
Os segundos são os "fundamentos da excelência gerencial contemporânea" (MPOG; SEGES, 2009, p.17), eles norteiam as ações do Modelo de Excelência em Gestão Pública (MEGP) ${ }^{24}$, um dos sustentos do GesPública. Estes fundamentos são,

[...] pensamento sistêmico [...]; aprendizado organizacional [...]; cultura da inovação [...]; liderança e constância de propósitos [...]; orientação por processos e informações [...]; visão de futuro [...]; geração de valor [...]; comprometimento com as pessoas [...]; foco no cidadão e na sociedade [...]; desenvolvimento de parcerias [...]; responsabilidade social [...]; controle social [...]; e gestão participativa [...] (MPOG; SEGES, 2009, p. 21).

Os fundamentos que direcionam as ações do GesPública compõem uma abordagem total à organização e aos envolvidos em seus resultados e impactos sociais. Portanto, são de crucial importância na concepção e no limiar das atitudes a serem desenvolvidas pelo Programa nas organizações públicas.

O Modelo de Excelência em Gestão Pública visa guiar os gestores públicos no almejar a atuação organizacional e a excelência em altos moldes. O MPOG e a SEGES representam a estrutura do Modelo de acordo com a figura abaixo. Ela expõe o Modelo em quatro blocos, o primeiro é definido como idealização por ser composto de Liderança, Estratégias e Planos, Cidadãos e Sociedade; o segundo, cumprimento combinado de Pessoas e Processos; o penúltimo, controle ao demonstrar os efeitos, Resultados; e o último, argúcia da organização por manter as Informações e Conhecimento. Estes tópicos são os critérios observados para atingir e avaliar as organizações no ambiente GesPública e seu prêmio nacional (MPOG; SEGES, 2008, p. 17).

Figura 6: Representação Gráfica do Modelo de Excelência em Gestão Pública.

\footnotetext{
24 “O modelo de excelência em gestão, de padrão internacional, expressa o entendimento vigente sobre o "estado da arte' da gestão contemporânea nacional e internacional, e é a representação de um sistema de gestão que visa aumentar a eficiência, a eficácia, a efetividade e a relevância nas ações executadas. É constituído por elementos integrados, que orientam a adoção de práticas de excelência em gestão com a finalidade de levar as organizações públicas brasileiras a padrões elevados de desempenho e de qualidade em gestão" (MPOG; SEGES, 2009, p. 15).
} 


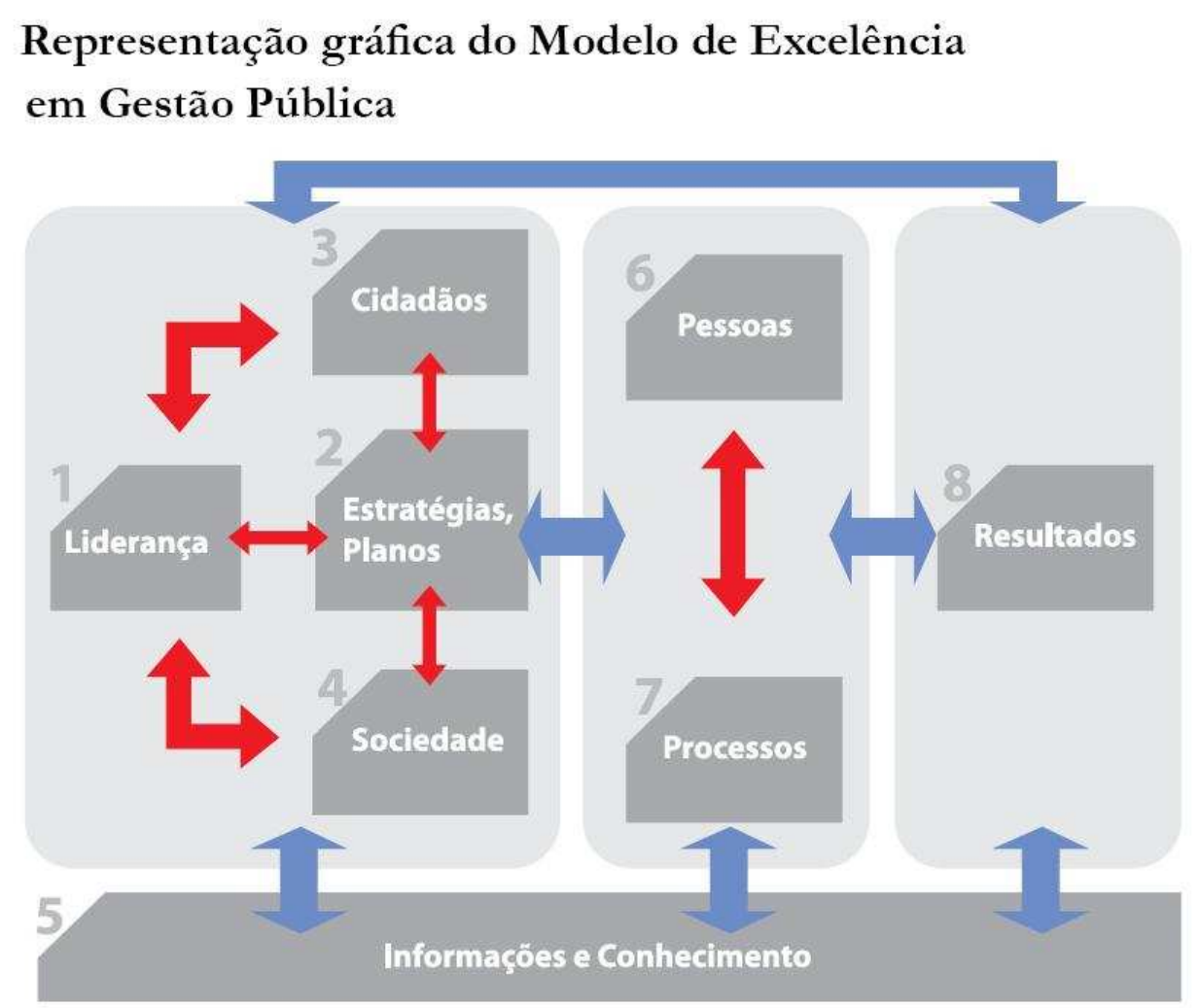

Fonte: MPOG; SEGES. Documento de Referencia: Gespública disponível em www.gespublica.gov.br, acesso dia 05 de maio de 2009, p. 09.

A terceira veia, caminho que alimenta o capital intelectual e operacional do programa GesPública é a Rede Nacional de Gestão Pública em suas relações e disponibilidades individuais e organizacionais voluntárias para a melhoria da administração pública no Brasil.

A quarta pilastra do Programa é a Carta Brasília ${ }^{25}$, documento redigido a partir do Congresso CONSAD de Gestão Pública em maio de 2008 pelo Ministério do Planejamento, Orçamento e Gestão e pelo Conselho Nacional de Secretários Estaduais de Administração (CONSAD), em que são colocados os focos de melhorias da administração pública, além dos seus princípios e considerações.

Dentre os pontos abordados para mudança no serviço público estão apontados, a gestão de pessoas, visualizando o servidor; os modelos de gestão, para a facilidade burocrática; instrumentos do ciclo de gestão, utilização correta do orçamento; prevenção e combate à corrupção; realização de estudos e pesquisas para subsidiar as políticas e diretrizes (MPOG, 2008). Os congressos, reuniões e demais atividades de discussão e reflexão sobre o desempenho da administração pública em sua efetividade expõem a preocupação e a 
necessidade dos órgãos de planejamento em transformar as ações tomadas e os paradigmas existentes em organismos públicos e auxiliam o Programa a permear suas diretrizes.

A quinta é o Código de Ética do Programa. Ele estabelece regras para os voluntários e servidores públicos envolvidos no GesPública além de indicar os devidos meios de punição a possíveis erros das partes integradas no Programa.

Estes alicerces são adotados pelo Programa, pois, são compreendidos pela administração pública como concepções máximas desta gestão e sevem de sustentáculo para diversos planejamentos e sua efetivação.

A estrutura estratégica do Programa Nacional de Gestão Pública e Desburocratização é, de acordo com o MPOG e a SEGES,

Figura 7: Dimensionamento Estratégico do Programa Nacional de Gestão Pública e Desburocratização.

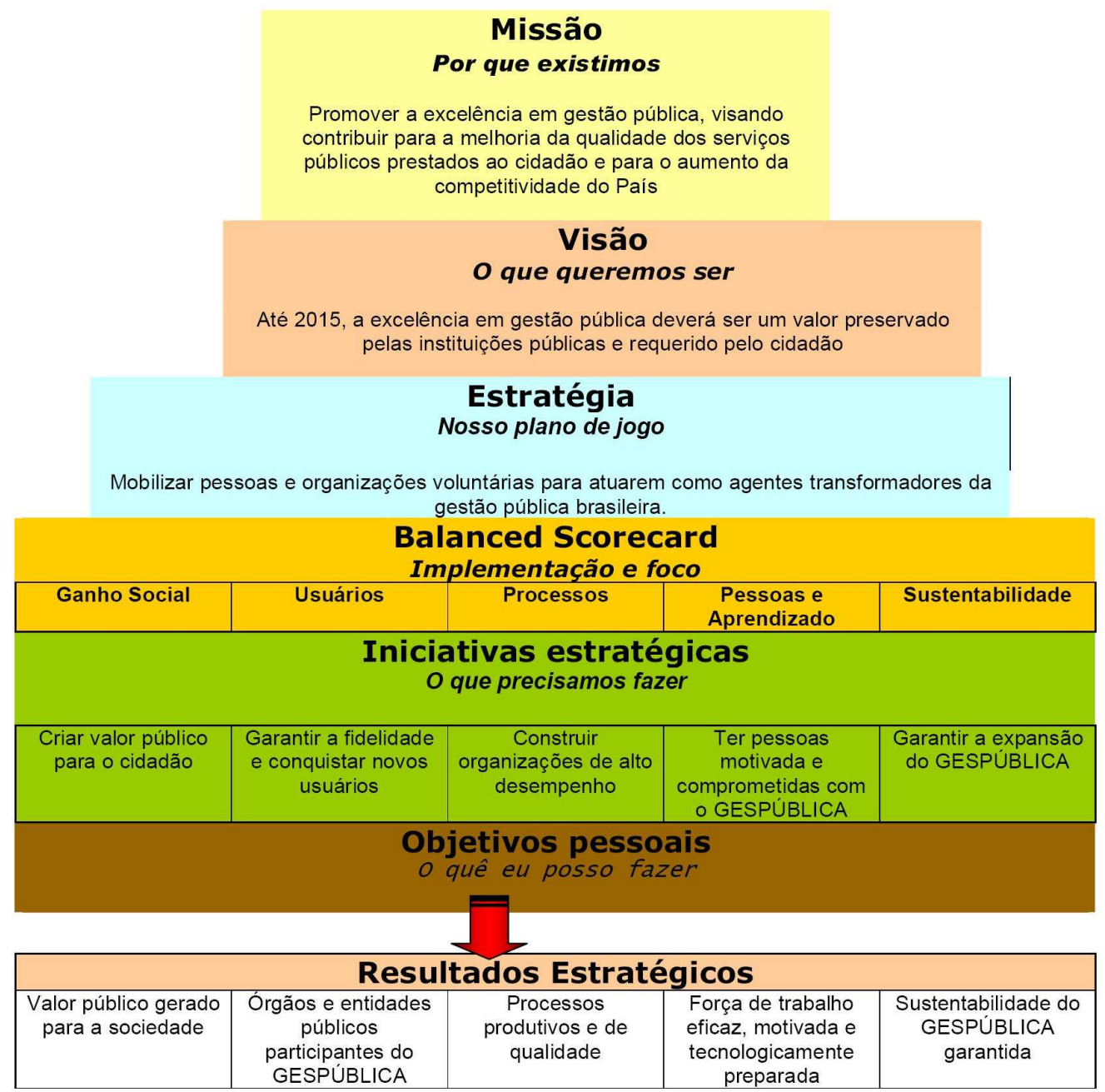

\footnotetext{
${ }^{25}$ Documento em anexo.
} 
Fonte: Fonte: MPOG; SEGES. Documento de Referencia: Gespública disponível em www.gespublica.gov.br, acesso dia 05 de maio de 2009, p. 19.

A partir deste delineamento de idéias, o Programa, através de seus agentes e ao modificar pouco a pouco o exercício nos órgãos públicos disponíveis para sua efetivação, transforma o serviço público brasileiro qualitativo aos olhos de seus cidadãos e, destaca-se no cenário internacional em gestão pública expondo-se como referencia a outras organizações nacionais e internacionais.

Como qualquer programa de alcance nacional, o GesPública possui diversos núcleos espalhados pelo Brasil. Sua gestão é descentralizada e conta com o apoio dos voluntários individuais e organizacionais.

Esta descentralização dá-se pelos Núcleos Estaduais. Os mesmos, ao par da Secretaria Executiva coordenam e guiam as atitudes do Programa em cada região abordada. Isto permite que cada localidade expresse sua dificuldade e experiência na aplicação do cronograma.

Esta manifestação de fenômenos é avaliada pelo Comitê Gestor e pela Secretaria Executiva que ponderam e aconselham os Núcleos a partir do Código de Ética às futuras atitudes dos envolvidos no cumprimento do Programa. O controle realizado por estes departamentos permite e viabiliza a uniformidade dos procedimentos e processos nacionalmente, sem modificações e descumprimentos de etapas (MPOG; SEGES, 2009).

O GesPública é formado por três plataformas: uma estratégica, sendo de responsabilidade do MPOG “[...] a definição das diretrizes estratégicas de governo para o GESPÚBLICA e, conseqüentemente, a aprovação do planejamento estratégico do Programa [...]", a condução do Programa neste nível é de responsabilidade do Comitê Gestor que “[...] tem por objetivo estabelecer as diretrizes para o planejamento das ações do Programa, bem como coordenar e avaliar a execução dessas ações [...]”. Segunda, de coordenação, Gerência Executiva de responsabilidade do Departamento de Programas de Gestão (DPG) localizado na SEGES, esta administra a Rede Nacional de Gestão Pública “[...]propondo, desenvolvendo e orientando a implementação de projetos e ações com vistas a garantir resultados efetivos na execução das diretrizes formuladas para o Programa [...]”, desta maneira esta Gerência lida com a direção dos Núcleos Estaduais e Setoriais, e dos voluntários em rede nacional. E terceira, executiva, composta pelos Núcleos Estaduais, os quais “[...] respondem pelo planejamento, gerenciamento e execução das ações do GesPública no âmbito dos estados respectivos [...], 
Núcleos Setoriais, “[...] são unidades técnicas especializadas do Programa para áreas setoriais específicas [...] planejam, gerenciam e executam as ações do Programa no seu setor de atuação", é importante frisar que estes núcleos são formados pelos voluntários da Rede, por fim estes últimos compõem o plano executivo (MPOG; SEGES, 2009, p. 22).

Estas plataformas permitem ao Programa uma unidade administrativa e ideológica. Isso, ao auxiliar e acompanhar os colaboradores envolvidos nos processos de execução do GesPública conforme necessitam.

Lima, expõe essa ideologia do GesPública em uma dimensão que permite a clara visualização das chaves do Programa em seu ambiente de participação e integração com os colaboradores.

Figura 8: GesPública e suas dimensões.

\begin{tabular}{|c|c|}
\hline Dimensão & GESPÚBLICA \\
\hline \multirow[t]{2}{*}{ Complexidade e incerteza } & $\begin{array}{l}\text { Realizar o GESPÚBLICA implica } \\
\text { influenciar e receber influências de uma rede } \\
\text { complexa de atores internos e externos. }\end{array}$ \\
\hline & $\begin{array}{l}\text { Há elementos fortes e determinantes que } \\
\text { atuam no processo decisório com diversos e } \\
\text { diferentes pontos de interação. }\end{array}$ \\
\hline $\begin{array}{l}\text { Refere-se ao número e à variedade de } \\
\text { elementos e de interação no ambiente do } \\
\text { sistema de decisão. }\end{array}$ & $\begin{array}{c}\text { Nessa rede atuam atores com força e } \\
\text { motivação a favor e contra o programa. Há } \\
\text { uma grande quantidade de atores com força, } \\
\text { porém sem motivação. Esses têm sido o } \\
\text { espaço do jogo mais crucial para o } \\
\text { GESPÜBLICA, pois tais atores, por não } \\
\text { terem motivação, podem ser facilmente } \\
\text { convencidos a jogar contra e, como têm } \\
\text { força, fazem a diferença, como já fizeram. } \\
\text { Felizmente em algumas batalhas, não na } \\
\text { guerra. }\end{array}$ \\
\hline \multirow{2}{*}{$\begin{array}{l}\text { É o nível de informação e a possibilidade, em } \\
\text { função dela, de reorientar a política. }\end{array}$} & $\begin{array}{c}\text { A Rede Nacional de Gestão Pública, as } \\
\text { organizações que aderiram ao Programa e os } \\
\text { atores com força e motivação dão o feedback } \\
\text { necessário para manter em constante } \\
\text { processo de melhoria a política de gestão } \\
\text { pública formulada há quinze anos pelo } \\
\text { GESPÚBLICA. }\end{array}$ \\
\hline & $\begin{array}{l}\text { Atores - voluntários - com motivação e } \\
\text { relativa força têm garantido à execução plena }\end{array}$ \\
\hline
\end{tabular}




\begin{tabular}{|c|c|}
\hline & do Programa. \\
\hline $\begin{array}{l}\text { Controle } \\
\text { Corresponde ao grau de garantia que um ator } \\
\text { ou um pequeno grupo de atores pode dar à } \\
\text { execução plena da política proposta. }\end{array}$ & $\begin{array}{l}\text { Os atores governamentais ainda não podem } \\
\text { ser apresentados como garantia à execução } \\
\text { plena do GESPÚBLICA. }\end{array}$ \\
\hline $\begin{array}{l}\text { Corresponde ao nível de estabilidade na } \\
\text { implementação da política. }\end{array}$ & $\begin{array}{l}\text { Os quinze anos do Programa evidenciam sua } \\
\text { estabilidade. O fator crítico para o sucesso } \\
\text { desta estabilidade está no voluntariado, } \\
\text { atualmente integrado na bem-sucedida Rede } \\
\text { Nacional de Gestão Pública. }\end{array}$ \\
\hline $\begin{array}{l}\text { O povo genericamente é a audiência na } \\
\text { política pública, mas para cada caso há } \\
\text { segmentos diferentes de espectadores. }\end{array}$ & $\begin{array}{l}\text { A audiência do GESPÚBLICA é integrada } \\
\text { pelos órgãos e entidades da administração } \\
\text { pública brasileira, os servidores públicos e os } \\
\text { cidadãos usuários dos serviços públicos } \\
\text { prestados pelos órgãos e entidades que dele } \\
\text { participam. }\end{array}$ \\
\hline
\end{tabular}

Fonte: LIMA, 2007, p.201.

Os ambientes descritos por Lima permitem uma percepção realista do Programa, onde não somente acontece bonança, mas também, situações distintas dessa ventura e, que influenciam diretamente no decorrer da aplicação do GesPública. Ao lado destas situações adversas consta a não-consciência de alguns com relação à necessidade de melhorias na administração pública.

De tal sorte, toda a estrutura e embasamento do Programa o tornam firme para sua aplicação naquelas organizações que possuem consciência da extrema precisão do setor em reformar a administração pública. Infelizmente, nem todas as esferas e dimensões do poder público percebem e admitem a necessidade de mudanças. O próprio formulador da ideologia do Programa, Paulo Daniel Lima Barreto, expressa a resistência da administração pública em adotá-lo ao expor que, "a proposta GesPública, apesar do tempo decorrido, dos choques com o poder político-burocrático dos quais foi vítima, conseguiu manter-se intacta, em contínuo aperfeiçoamento" (LIMA, 2007, p. X).

Os órgãos responsáveis pelo GesPública declaram que há indispensabilidade da otimização dos processos de labor, diminuindo o excesso burocrático para evitar desperdícios de tempo, dinheiro e capital intelectual da população brasileira. O próprio governo em suas diversas 
escalas disponibiliza este Programa como ferramenta para o alcance destes objetivos (MPOG; SEGES, 2009).

O programa GesPública trabalha, em sua abordagem organizacional, com o levantamento, a identificação de processos e as melhorias a estes em vista da desburocratização.

As etapas executadas pela equipe de voluntários são diversas, qualificadas em quatro processos. O primeiro é o planejamento da simplificação, ele envolve os pré-requisitos da simplificação administrativa e a elaboração do plano de trabalho, que resultam no segundo processo chamado mapeamento de processos, neste está o levantamento das atividades e normas, a identificação dos elementos de iteração do processo e o desenho dos fluxogramas atuais, eles efetivam no terceiro processo, análise e melhoria de processo, por sua vez compõe a árvore de soluções, a modelagem do processo e o sistema de medição de desempenho realizando o quarto processo, implementação das melhorias, este possui a proposta de simplificação e a implementação do novo processo, por fim da metodologia.

Para uma boa gestão em órgãos públicos é preciso, segundo o GesPública, o delineamento das situações e execução das melhorias imaginadas pelos próprios gestores e servidores das organizações uma vez que eles conhecem a realidade vivida e os procedimentos realizados com o apoio da equipe voluntária da Rede. Segundo Maranhão e Macieira a gestão e sua efetividade precisam acima de tudo de claridade em seus objetivos e de ferramentas de medição, ponderação dos processos, para que os resultados sejam alcançados efetivamente. Este pensamento é revelado no trecho,

[...] definição da estratégia organizacional, seguindo-se a fixação dos objetivos a serem alcançados. Para se ter uma medida objetiva do grau de sucesso na obtenção dos objetivos, são definidos Indicadores de Desempenho. Operacionalmente, os resultados são gerados pelos processos, que requerem $\mathrm{FCS}^{26}$ para a operação eficiente e eficaz (2004, p.80).

É extremamente necessário também, que nas organizações os processos identificados e executados estejam conexos, independente de interpelações e influencias no conjunto final, estes por sua vez devem formar uma "rede [..](networking) da organização" (MARANHÃO; MACIEIRA, 2004, p.13). A rede auxilia não somente na eficiência e eficácia do labor executado como também nas relações internas, na determinação de trabalhos e na identificação de responsáveis. O GesPública permite através de sua aplicação na organização

\footnotetext{
${ }^{26}$ Fatores Críticos de sucesso.
} 
este estabelecimento de networking, uma vez que, com os processos traçado e delimitados os responsáveis, a organização tem que se organizar e incentivar a comunicação para o cumprimento de seus objetivos finais.

Os processos devem ser bem definidos e trabalhados nas organizações para trazerem benefícios de participação e empenho dentro da entidade, isto faz com que os indivíduos se sintam valorizados e responsáveis por aquilo que fazem (MARANHÃO; MACIEIRA, 2004), além de contagiar o cliente externo com agilidade, efetividade de serviços que talvez não fossem tão bons em um passado onde não se utilizava este método.

Além disso, os processos devem estar a todo o momento sendo monitorados em sua estrutura para evitar o excesso de aparato burocrático e para aperfeiçoar os procedimentos tanto quanto for necessário na visão dos envolvidos a partir das demandas (LIMA, 2007). E para as organizações públicas, o GesPública fortalece-se como instrumento de regressão deste abuso de burocracia.

Muitas entidades não adotam o modelo de processos organizacionais por vários motivos dentre eles, a ausência de conhecimento sobre os componentes e suas variáveis no processo a ser lidado, sobre a abordagem, estereótipos organizacionais, dentre outros (MARANHÃO; MACIEIRA, 2004). Em compensação, as organizações que seguem este protótipo mostram diversas particularidades, algumas são: “objetivos claros a serem alcançados [...]; há indicadores de desempenho (ou dos resultados) desses processos [...]; as pessoas realizam os seus processos de trabalho de forma estruturada, previsível e organizada" (idem, 2004, p.15), e apresentam os resultados concretos ao público alvo conforme solicitações.

Logo, existem diversas vantagens na aplicação de modelos para a qualidade, como o GesPública, nos serviços públicos. Além de diagnosticar, estabelecer e monitorar os processos, eles diminuem os custos e a energia organizacional desperdiçada na execução dos serviços e, diminuem o exagero de burocracia fazendo com que os objetivos organizacionais sejam executados de maneira rápida, concisa e determinada ao cidadão, ao trazer resultados à sociedade.

Lima (2007) assinala que admitir o Programa como guia diário de gestão é ter a visão de analistas, indicar a todo instante os possíveis caminhos do progresso e perceber a transformação de concepções daqueles envolvidos. Este autor revela que os efeitos do Programa são reduzidos uma vez que houve maior resistência da cadeia pública que adoção 
deste, ele ainda coloca que os resultados poderiam ter sido bem maiores se a alta administração não utilizasse de indiferença com o GesPública.

Ainda, dentro da perspectiva do Programa emergem metas, planos e prêmios para o reconhecimento daqueles que cumprem o plano no serviço público. Hoje, o GesPública está dentre os programas mundiais de qualidade total que geram resultados e serve de referência às empresas privadas na reengenharia de processos e qualificação de serviços. Portanto cabe à população observar as melhorias daqueles que fizeram por onde alcançar a melhoria e a desburocratização e, cobrar daqueles que não aceitam talvez por egoísmo, uma proposta que procura nivelar o serviço público e seus resultados em um nível de qualidade internacional em eficiência e eficácia.

\subsection{Ministério do Turismo $X$ Programa Nacional de Gestão Pública e Desburocratização}

O GesPública tem se mostrado como uma importante ferramenta de gestão nos órgãos públicos federais que já o adotaram. Assim como estes órgãos, o Ministério do Turismo pode alcançar resultados otimizados e rapidamente, a partir da captação do Programa, suas abordagens e atuação em sua organização.

A SEGES aborda que,

O Estado democrático tem sido instado, de forma cada vez mais veemente, pelos diversos segmentos da sociedade, a cumprir sua função precípua de desenvolver políticas públicas direcionadas para a garantia da igualdade de oportunidades, dos direitos básicos de cidadania e do desenvolvimento sustentado, produzindo resultados eficientes e efetivos. Ao mesmo tempo, a sociedade está cada vez mais complexa quanto à sua organização, à dinâmica de funcionamento e á demanda por serviços públicos (2009, p.31).

Assim, a maneira de gerir dos órgãos públicos tem mudado por causa do surgir de uma demanda mais crítica e criteriosa por parte se seu público alvo, o cidadão. Este tem observado os atos e acompanhado o desenvolvimento dos serviços públicos e sua qualidade fazendo com que os gestores e colaboradores se empenhem no labor diário. Do mesmo modo, a gestão do Ministério do Turismo em seus diversos setores deve aprimorar, melhorar seu foco para o cidadão e para a sociedade que o acomoda, não só porque a sociedade exige, mas como forma de explicitar e criar valor público ao cidadão dos serviços prestados por este órgão. 
A relutância em adequar-se a modelos de gestão pública não é concernida apenas pelo MTUR, porém em diversos outros setores. Os órgãos de planejamento e gestão da administração pública perceberam a dificuldade em convencer os altos gestores da aplicação de novas abordagens nesta gestão. Houve relutância por parte dos atingidos, não porque os gestores fossem só teimosos, mas, pelo histórico de mudanças na administração pública e sua ineficácia.

Contudo, existem, hoje, diversos resultados dos programas de qualidade em gestão pública e dentre eles destaca-se o GesPública, considerado mundialmente o melhor instrumento nesta área. Além do Programa, existe o reconhecimento, o Prêmio Nacional de Gestão Pública, das organizações que buscam a excelência por parte do governo.

Segundo GESPÚBLICA (2009), as entidades buscam a capacitação essencial ao entrarem no GesPública e realizam uma avaliação de sua gestão, em uma escala de 0 a 1000 pontos gradativamente, primeiro uma de 250, depois a de 500 e por fim a de 1000 . As organizações que efetivamente participam deste Prêmio são aquelas que conseguiram chegar a escala de 1000 pontos, ou ainda, organizações que possuem uma política e ações voltadas à qualidade na gestão e em busca pela excelência.

Porém nem todos os órgãos acreditam na eficácia do método ou do Prêmio. Sobre isso a SEGES interpõe que

As antigas suposições e modelos de conhecimento perfeitos e restritos a áreas especificas precisam ser mudados diante da complexidade dos problemas sociais e da velocidade do desenvolvimento tecnológico e do conhecimento, que os impõe o desafio da aprendizagem contínua (2009, p.31).

Ou seja, a mudança na gestão pública com ênfase em seu desempenho é necessária, uma vez que o rápido fomento das informações e tecnologias exige e precisa de uma postura de melhoria constante e, para isso o MPOG propõe o GesPública.

GESPÚBLICA (2009) coloca que existe aceitabilidade pelos órgãos públicos com relação ao GesPública, mesmo porque vários agentes de empresas públicas que já empregam o Programa nas suas organizações estão ocupando altos cargos públicos e levam consigo a visão de mudança, de desburocratização e qualificação dos serviços.

No entanto existe entraves com relação a aplicação do Programa, sobre a vontade interna de mudança e, sobre a vontade política, ou seja, um somente tem a percepção da necessidade de mudanças mas os demais não e nem querem modificar. Ainda segundo GESPÚBLICA 
(2009), "o trabalho inicial gera a facilidade de mudança. Se você passar a fazer direito e você trabalha menos", portanto há grande quantidade de trabalho no emprego do Programa, mas este esforço é recompensado uma vez que se aprende a agir com sustentabilidade.

Há também alguns órgãos, como o TCU e a CGU, que querem utilizar o Programa em uma versão diferenciada, a de pré-requisito para uma auditoria em entidades públicas. Porém, a função do GesPública não é a de ser critérios para auditorias ou mesmo liberações de orçamento, adversamente o Programa trabalha, essencialmente, com o livre-arbítrio das organizações públicas. Assim sendo, o GesPública disponibiliza seus colaboradores para a aplicação do Programa partindo do princípio que a organização percebe a necessidade de mudanças em sua gestão, processos e resultados.

Com base neste pensamento, o MTUR pode dispor-se, originalmente, de seu modelo de planejamento por adição de valores, fazendo o mesmo ser superiormente desenvolvido pelo GesPública. Deste modo, o MTUR além de usufruir e lidar com os critérios já existentes (Resultados, Atividades, Informações e, Planejamento e Gestão), adotaria mais quatro (Cidadãos, Sociedade, Pessoas e Liderança). Estes últimos inserem e transformam a gestão, o fomento das atividades e das metas existentes do Ministério em um formato sistêmico e de alcance total aos envolvidos na entidade.

Os módulos, resultados institucionais e operacionais entrariam no critério de Resultados. Os resultados controlados em suas diversas etapas de processamento permitem a manutenção da qualidade ao cidadão, assim como qualquer realinhamento de posturas e procedimentos dos departamentos do órgão.

Com esta sistematização, o MTUR atingiria as quatro metas, programas e projetos de maneira mais rápida que a atual. A apresentação da conquista destes resultados à população faria com que o cidadão visse o Órgão sob um novo prisma, com um diferente valor.

Ademais, o controle sobre estes resultados e o retorno da própria sociedade a cerca destes efeitos poderia demonstrar, por exemplo, a necessidade de modificar os objetivos específicos da organização e a eficácia dos planos e metodologias empregados. Demais a mais, a estipulação de instrumentos de avaliação de desempenho deve expor o desenrolar, decorrer, e os efeitos destes resultados pela comprovação da satisfação das necessidades dos circundados e interessados e pela comparação a outros órgãos, gerando uma cadeia de alimentação do ciclo de gestão para a qualidade completa. 
O núcleo, atividades, seria desenvolvido pelo critério Processos. Este, por sua vez, traria a identificação, o mapeamento, o desenvolvimento e a execução dos processos do Ministério e seria de grande valia uma vez que, esta entidade identificaria através de debates e discussões entre seus colaboradores, visando as metas previstas e o PNT, os objetivos reais da organização, as prioridades a serem trabalhadas para alcançá-los, os objetivos específicos da organização, os fluxos destes e também, a indicação dos responsáveis de cada um deles. Este módulo chamado Processos em sua explanação e execução final diminui custos e aperfeiçoa os resultados ao cliente, cidadão.

O elemento, informação, seria progredido pelo chamado Informações e Conhecimento, fomentando os núcleos de arranjo de informação para as ações do Ministério e os de reflexo desta atividade na sociedade brasileira. As informações e o conhecimento a cerca da gestão do macro e micro ambiente organizacional é de fundamental importância ao Ministério, a ciência dos fatos ocorridos é de imprescindível consulta aos colaboradores em suas decisões e labores nesta entidade, ao trade e aos cidadãos.

A plataforma Planejamento e Gestão seria aperfeiçoada pela considerada, Estratégias e Planos. As estratégias e os planos do Ministério seriam atingidos quando melhor clarificados e delineados. As estratégias permitiriam uma visão não só idealizada, porém concretizada através dos planos de ação. Não deixando aos gestores de áreas a função de determinar a quantidade e qualidade destas ações, mas a organização como um todo.

O planejamento deste bloco beneficiaria os serviços, produtos e processos de acordo com as divisas afins às necessidades deste conjunto de precisões (SEGES, 2009).

Assim, o Ministério ganharia ao integrar a abordagem prática existente em um ambiente de maior raciocínio, de maior exploração das situações futuras do turismo brasileiro, ao visionar e ao preparar os campos necessários para tomar diversas atitudes de fronte os cenários nacionais. Isso, certamente, otimizaria e aumentariam as metas e propostas de execução do turismo.

Por fim seriam incluídos outros quatro módulos para o alcance de outros pontos não muito trabalhados pelo Ministério hoje ${ }^{27}$ : Pessoas, Liderança, Cidadãos e Sociedade.

O critério Pessoas é atingido diretamente pelo elemento chamado Processos, no primeiro estão os indivíduos que integram o Ministério, ou seja, os colaboradores. O módulo, Pessoas

\footnotetext{
${ }^{27}$ Análise a partir de seu modelo de adição de valores.
} 
abrange a composição dos cargos, a disposição do trabalho e, a direção dos resultados dos colaboradores e suas equipes em toda a organização.

Ele requer o incentivo, a capacitação e a propensão de um ambiente motivador ao fazer com que os rendimentos dos trabalhos sejam efetivados de maneira ágil e correta, ao impulsionar a qualidade de vida dos envolvidos, isto, além de persuadi-las ao aumento de conhecimento através de capacitações.

O MTUR ao estabelecer os processos e suas redes de contato, assim como seus responsáveis, torna o colaborador mais independente em suas ações no contexto da entidade, por tornar-lhe agente sofredor e causador de suas atitudes na empresa. Para a manutenção deste contexto de labor independente e sistêmico, para a especialização destes funcionários em suas aptidões é necessária a criação de um ambiente organizacional que alimente a motivação e o conhecimento dos processos.

A abordagem da liderança, segundo a SEGES, é a "criação de um ambiente propício à inovação e ao aperfeiçoamento constantes, ao aprendizado organizacional, ao desenvolvimento da capacidade da organização de se antecipar e se adaptar com agilidade às mudanças no seu ecossistema e de estabelecer conexões estratégicas" (2009, p. 22). Desta maneira os gestores do Ministério do Turismo devem perceber o ambiente em que atuam de forma a antecipar-se às possíveis modificações e manter objetividade e os propósitos da organização.

O critério Liderança abraça também temas como a mudança cultural, o provimento do sistema de gestão e responsabilidade organizacional, transparência, igualdade entre outros. Com isto, a tomada de decisão seria diretamente atingida assim como a agilidade nos procedimentos para a mesma, facilitando a decorrência dos resultados.

A abrangência da Liderança não foca somente o ambiente interno da organização, mas inclusive o externo. Desta forma, neste critério também é exposta a maneira como o órgão, no caso Ministério do Turismo, lida com governança voltada ao trade turístico. Como incentiva, fomenta, apóia e administra a atividade turística no País.

Este ponto, em suas duas interposições, ao ser bem trabalhado e desenvolvido trás benefícios palpáveis à organização e a sociedade como um todo. Desta maneira, a Liderança atinge diretamente aos cidadãos, à sociedade e às estratégias e planos, assim com os mesmos à liderança em relação contrária. Ademais ela alimenta e é alimentada pelos resultados e pelas 
informações e conhecimentos, ou seja, a liderança influi e é influenciada podendo sofrer diversas alterações.

O critério Cidadãos promove a identificação do público-alvo da organização, a partir de seus serviços e representação, assim como a distinção de suas necessidades e o cumprimento da satisfação destas e, como o Ministério se prorroga em percebê-los. Este módulo também analisa as relações do Ministério com o cidadão, ou seja, como este órgão fortalece sua imagem e cria valor ao cidadão por suas ações.

O módulo, Sociedade aborda as competências do Ministério com relação à sociedade e localidades atingidas pela atividade turística em face do seu órgão público, por meio de atuações conforme as políticas públicas do setor. Este critério desperta a cidadania, através de incentivos de controle social e ético às atividades desenvolvidas.

A sociedade seria privilegiada de constituir um turismo sistêmico, entrosado e dnâmico em suas diversas áreas, bem estruturado e de acordo com regras e normas que a defendesse de posturas errantes e cobrasse atitudes regulamentadas, participando delas ativamente.

O GesPública é sistêmico, os oito elementos citados são desenvolvidos concomitantemente e divididos em quatro blocos, Planejamento ${ }^{28}$, Execução $^{29}$, Controle ${ }^{30}$ e Informações e Conhecimento $^{31}$. O bloco Informações e Conhecimentos, alimenta os de controle, a execução e o planejamento organizacional, além de receber informações dos três. O grupo Controle, é incitado pela Execução além de gerar efeitos de influência direta ao Planejamento, e este viceversa. E por fim o Planejamento nutre a Execução. Todo este aparato serve para maximizar e agilizar os efeitos e objetivos esperados por este e outros órgãos.

Muitas vezes a partir desta rapidez,

a natureza dos problemas enfrentados pelos governos [...] faz com que estejam cada vez menos suscetíveis a soluções precipitadas e temporárias ou a ficarem restritos à ação de um órgão ou instituição, isoladamente e, em alguns casos, a uma esfera de governo ou, até mesmo, a fronteiras nacionais (SEGES, 2009, p.32).

Este autor coloca ainda que,

nenhum órgão público atuando sozinho com base no modelo tradicional de áreas restritas de atividades e mandatos exclusivos, sem ações coordenadas e

\footnotetext{
${ }^{28}$ Composto da liderança, cidadãos, sociedade e estratégia e planos.

${ }^{29}$ Inclui as pessoas e os processos.

${ }^{30}$ Abrange os resultados.

${ }^{31}$ Contem em si as informações e conhecimento.
} 
integradas com outros órgãos e entidades, pode garantir a cobertura e a coerência necessária para as políticas nesse novo contexto (SEGES, 2009, p.32).

A SEGES expõe por meio destes parágrafos que as entidades públicas devem atentar-se com a multiplicidade de caminhos a serem seguidos, seus benefícios e efeitos, elas devem ainda estar atentas ao alcance de sua cadeia de produção e, por causa desta carga de responsabilidade, não esquecendo de sua natureza pública, as entidades precisam procurar gerir com base em algum modelo de gestão as suas atividades corriqueiras, para isso a intersecção entre os departamentos e órgão é de fato necessária ao bom desenvolver destas ações.

A partir desta realidade, o GesPública percebe que a qualificação do gerenciamento da administração pública é precisa, porém escassa. Com isso, este Programa tem desenvolvido a facilitação, desregulamentação e a conjectura de normas para as entidades públicas dos formatos de gestão, das atitudes e da gerencia pública, de maneira a criar estima pública de caráter prático para a coletividade (SEGES, 2009).

GESPÚBLICA (2009) expõe que o GesPública tem demonstrado diversos resultados por meio de órgãos oficiais. Várias organizações que aderiram o Programa estão na mídia como entidades grandiosas em busca pela qualidade e excelência. Porém a quantidade de órgãos públicos e seus setores que adequaram-se ao Programa é pouca por causa de sua natureza de conscientização e educação aos órgãos governamentais e à sociedade, ainda em pequena escala.

O Programa desenvolve uma gestão focada no cidadão, fonte de demanda do setor público, e gera valor agregado no serviço a este público. Isso além de, contribuir à competitividade do País e melhorar a qualidade dos serviços prestados pela administração pública. O ponto mais importante do GesPública, talvez, tenha sido a abordagem da administração pública como entidade pública. Tendo em vista que esta organização tem deveres e normas a serem cumpridos além de possuir a essência pública.

GESPÚBLICA (2009) interpõe sobre a criação de valores aos cidadãos e sobre a coisa púbica que a constituição moral das organizações públicas deve orientar-se pelos cinco princípios constitucionais: legalidade, impessoalidade, moralidade, publicidade e eficiência. Colocando estas essências em prática e associando-os a uma administração pública agradavelmente qualitativa, os cidadãos receberão o que lhe é de direito e em consequiência o valor será 
criado. Isto é concedido pelo GesPública através do comprometimento das pessoas, o foco ao cidadão e à sociedade.

Além do mais, o turismo brasileiro a par do GesPública e suas práticas contemporâneas, assim como outros órgãos, traria um aumento nos resultados. De mais a mais, isto permitiria uma execução da qualidade no âmbito turístico nacional, a efetividade das propostas e aumentaria a competitividade do Ministério e do turismo nacional frente a outros mercados mundiais.

Portanto, assim como em outras entidades públicas o Ministério ganharia e melhoraria em diversos setores. A aplicação do modelo de gestão GesPública traz ao cidadão melhorias assim como ao órgão envolvido. Faz-se necessário ao órgão brasileiro de turismo a adoção do GesPública, um modelo de gestão que visa a qualidade com foco no cliente e traz resultado a todos os envolvidos. Em suma, o Programa faz toda a diferença em uma organização e nesta sua ausência é latente. 


\section{MÉTODOS E TÉCNICAS DE PESQUISA}

\subsection{Delineamento da Pesquisa}

Os processos compõem as ações de várias empresas e governos. Para diminuir a burocracia dos diversos objetivos em uma organização é necessário um estudo detalhado e focado na realidade por ela vivida. A partir do estudo dos cenários e dos excessos burocráticos da organização é possível estabelecer critérios para melhoria e agilidade no andamento dos serviços finais. Em vista disto, existem diversos programas de qualidade em prestação de serviços; em foco da identificação, análise e melhoria em processos organizacionais e por consequiência premiações para as empresas que alcançarem à qualificação em gestão e almejam a excelência.

O Programa Nacional de Gestão Pública e Desburocratização (GesPública) objetiva a qualidade na prestação de serviços públicos e em conseqüência o fim ou diminuição extrema da burocracia nos processos públicos. O Ministério do turismo por fazer parte da administração pública compondo os órgãos governamentais, deveria seguir este programa em seus diversos departamentos e níveis. Não somente para realizar uma boa gestão, mas para visualizar e atingir o cidadão em suas atividades em prol da atividade turística nacional e seu desenvolvimento, ao não deixar de lado suas visão, metas e objetivos.

Essa pesquisa tem cunho documental, dedicada à investigação de documentos visando o levantamento de dados oficiais sobre o assunto a ser abordado; bibliográfica, ao abordar as fontes disponibilizadas ao público geral de caráter estritamente científico. E de campo exploratório, que tem a finalidade de levantar dados precisos a cerca do fenômeno (MARCONI e LAKATOS, 2005).

Foi realizada uma entrevista, com questionário aberto, uma sobre os processos na aplicação do programa GesPública e seu impacto nas organizações públicas com o responsável pelo Prêmio Nacional de Gestão Pública com base na SEGES.

Foi utilizada uma carga horária aleatória para a concretização do levantamento de referencial bibliográfico e documental. A pesquisa de campo, porém, foi marcada para o dia 29 de maio de 2009, no período matutino.

O processo de melhoria de qualidade na prestação de serviços é necessário para a otimização de resultados e objetividade em ações. No ambiente público sofredor de excessos burocráticos o estabelecimento da metodologia por processos é necessária uma vez que exige-se precisão e 
agilidade em sua extrema complexidade, abrangência de raciocínio e geração de consequiências na sociedade.

Ao realizar entrevista na Secretaria de Gestão sobre a contribuição do programa Gespública, será possível perceber as discrepâncias no processo de aplicação do mesmo assim como a aceitabilidade do Programa na escala federal. A pesquisa bibliográfica é de referencial e embasamento teórico para o prosseguir da análise.

A partir do embasamento teórico do turismo, de seu Ministério, sobre a Qualidade, focando o GesPública é possível compreender as metas, os objetivos do Ministério como órgão de fomento turístico brasileiro e as melhorias que este Programa pode trazer a uma organização pública disponível em aplicá-lo.

Com as respostas dos questionamentos à SEGES poderá se perceber e compreender as ações, a aplicabilidade, os entraves e as melhorias do Programa em órgãos públicos assim como sua aceitação nestes, bem como, os benefícios do último em relação ao ambiente turístico brasileiro.

\subsection{Descrição das variáveis de pesquisa}

Esta pesquisa fundamentalmente exploratória, segundo Schluter (2003, p. 72), “consiste em descobrir novas idéias e novas perspectivas", e objetiva necessariamente a

[...] familiarização com o tema a ser estudado; elaboração de uma hipótese; formulação de um problema que será estudado com maior precisão no futuro; familiarização com os conceitos; reunião de informação sobre possibilidades práticas para realizar pesquisas nos moldes da vida atual; oferecimento de informação detalhada sobre problemas considerados urgentes por pessoas que trabalham em um determinado campo de relações sociais [...] (SELLTIZ apud SCHLUTER, 2003, p. 72).

São utilizados documentos duas organizações em especial, o Ministério do Turismo Brasileiro e a SEGES, este último faz parte a pesquisa de campo.

O Ministério do Turismo foi criado em 2003, ao objetivar o fomento do turismo no Brasil em diversos aspectos, tanto em destinos e atrações como na movimentação profissional do trade em relação à sociedade.

A Secretaria de Gestão é um órgão do Ministério do Planejamento, Orçamento e Gestão desde 2007. Sua missão é a de "desenvolver políticas transformadoras de gestão para aumentar a capacidade de governo" e a sua visão de futuro é a de "tornar o Estado referência em gestão" 
(SEGES, 2008). Ela possui o GesPública como uma das maneiras de modificar a gestão pública no Brasil.

A pesquisa de campo foi concretizada por meio de técnica de pesquisa de opinião, neste ambiente, entrevistas não-estruturadas focalizadas no programa GesPública à SEGES. As questões foram abertas, de fato e ação. Schlüter afirma sobre estes últimos que "referem-se a questões concretas e tangíveis [...] a atitudes e decisões [...]" respectivamente.

Na Secretaria de Gestão as perguntas visaram a aplicação do Programa na escala federal, as dificuldades e os resultados obtidos até então.

Foi intencionada a realização da mesma espécie de entrevista com os gestores gerais do Ministério do Turismo, Ministro do Turismo ou ainda o Secretário Executivo. Porém, ao chegar em tal órgão, o acesso aos profissionais intencionados foi impedida através de indicações e o envio a outras subáreas que talvez pudessem corresponder ao uni-las às funções exercidas por eles.

\subsection{Participação do estudo}

Desta forma, o único participante deste estudo proveu da Secretaria de Gestão, que compõe o Ministério do Planejamento, Orçamento e Gestão.

Neste órgão foi realizada entrevista com o Senhor César Viana, Gerente do Prêmio Nacional da Gestão Pública, pela ciência nos distintos setores do GesPública, articulação na Secretaria para o trabalho e reconhecimento dos órgãos que atingiram um patamar de qualidade nos serviços públicos.

\subsection{Procedimentos e instrumentos utilizados na Coleta e Análise de dados}

A pesquisa em campo se deu por entrevista não estruturada, com perguntas abertas, de fato e ação. Schlüter comenta alguns benefícios desta espécie de entrevista dentre eles, "permite obter dados relevantes e significativos para o estudo que está sendo realizado; permite uma situação de espontaneidade; [...]". Desta forma otimiza-se a obtenção de fatos e de análise dos mesmos.

O embasamento destas entrevistas foi levantado a partir de documentos disponibilizados pelos Ministérios acerca do conceito, estrutura e realização das atividades envolvidas neste estudo. 
A partir do resultado do campo foi possível perceber a posição do Ministério do Planejamento, Orçamento e Gestão por meio da Seges, para a prática do funcionamento do Programa e postura como auxiliadora na administração pública em gestão focada em resultados ao cliente externo. A análise dos dados permeou a teoria e o resultado da pesquisa de campo.

\subsection{Período de realização da Pesquisa}

O levantamento teórico foi realizado durante os meses de maio e junho de 2009.

A coleta de informações foi realizada na quinta semana do mês de maio de 2009, no dia 30, matutino. No dia 21(quinta-feira) do mesmo mês, foi executada uma visita no Ministério do Planejamento, Orçamento e Gestão, com a finalidade de localizar os responsáveis, contatar secretários e marcar entrevistas com os próprios. Ao chegar ao Ministério foi localizado o responsável que pessoalmente marcou a entrevista para o dia 30 de maio (sexta-feira).

\subsection{Comentários sobre o Processo de Coleta de dados}

Como a pesquisa de campo é de ordem qualitativa não foi utilizado nenhum parâmetro de análise estatística de dados.

No Ministério do Planejamento, Orçamento e Gestão o contato foi feito diretamente com o indivíduo a ser entrevistado e o mesmo correspondeu à solicitação de forma generosa e disponível.

A articulação na SEGES com relação ao Programa foi certamente digna de reconhecimento, uma vez que os colaboradores envolvidos nos processos do GesPública possuem ciência de todas as etapas e configurações de suas ações como auxiliadores de gestores públicos. 


\section{APRESENTAÇÃO E ANÁLISE DOS DADOS}

Os dados obtidos junto representante do programa GesPública serão apresentados conforme foram conseguidos. A entrevista foi transcrita e colocada na íntegra para a análise de seus resultados.

Como foi na entrevista o texto recorre de perguntas e respostas, assim como as interrupções e colocações dos que compunham o diálogo, César Pereira Viana, gerente do Prêmio Nacional de Gestão Pública e Ycleda de Oliveira dos Santos, autora deste estudo.

A análise dos dados é fundamentada partir dos dados almejados pelo gerente do Prêmio que são colocados, quando possível, frente à conjuntura do Ministério do Turismo, no capítulo em que há esta equiparação.

\subsection{Agrupamento, ordenação e descrição dos dados coletados}

\begin{tabular}{|l|l|}
\hline Chegada de Turistas ao Brasil - 1970- 2007 & $\begin{array}{l}\text { Fluxos de turistas no período que data o final } \\
\text { do século XIX e início do século XX. }\end{array}$ \\
\hline $\begin{array}{l}\text { Estrutura de Coordenação da Gestão } \\
\text { Descentralizada }\end{array}$ & $\begin{array}{l}\text { Nível de coordenações e caminho de } \\
\text { informações dos níveis governamentais. }\end{array}$ \\
\hline Gestão Descentralizada do Turismo & $\begin{array}{l}\text { Panorama da estrutura gerencial e metas do } \\
\text { MTUR. }\end{array}$ \\
\hline Estrutura Organizacional do MTUR. & Órgãos, setores e departamentos do MTUR. \\
\hline Mapa de Adição de Valor & $\begin{array}{l}\text { Apoio e suporte do MTUR para alcançar } \\
\text { resultados e metas. }\end{array}$ \\
\hline Representação Gráfica do MEGP32. & $\begin{array}{l}\text { Critérios e relação dos elementos que } \\
\text { compõemo Modelo. }\end{array}$ \\
\hline $\begin{array}{l}\text { Dimensionamento } \\
\text { GesPública. }\end{array}$ & $\begin{array}{l}\text { Posicionamento tático do Programa para } \\
\text { realização das ações. }\end{array}$ \\
\hline GesPública e suas dimensões & $\begin{array}{l}\text { GesPública e percepções a cerca de sua } \\
\text { aplicação. }\end{array}$ \\
\hline
\end{tabular}

\footnotetext{
${ }^{32}$ Modelo de Excelência em Gestão Pública.
} 


\subsection{Análise descritiva dos dados}

O primeiro dado, chegada de Turistas ao Brasil - 1970- 2007, expõe a quantidade de turistas vindos ao Brasil no período de 1970 a 2007. Percebe-se a presença de subidas e descidas de demanda neste fluxo, devido o ambiente internacional e nacional vividos.

Os segundo, terceiro e quarto permitem uma melhor visualização e percepção das composições do MTUR, assim como os caminhos das informações e hierarquização dos macroprogramas e metas do turismo nacional; além de expor qual e como é a estrutura hierárquica organizacional do MTUR.

O quinto dado, demonstra a plataforma de apoio e suporte do MTUR para alcançar suas metas, objetivos e resultados. Este dado apresenta implicitamente a ausência de alguns critérios importantes ao andamento das ações e alcances do Órgão.

O sexto coloca os elementos que baseiam o Modelo e suas interferências. Este Modelo é hoje um dos fundamentos do GesPública, além de ser composto por rudimentos considerados pela administração contemporânea fundamentais ao bom desenvolvimento de uma organização.

O sétimo apresenta o Programa com meios determinados para o alcance dos objetivos das e nas organizações onde é aplicado o GesPública.

O último, expõe a visualização do idealizador do Programa a cerca de sua aplicação em geral. Todos, unidos, permitem a verificação de dados importantes para a concretização deste estudo, o turismo no Brasil, seu Ministério, estrutura e administração organizacional, a teoria contemporânea de administração pública e o GesPública, e possibilita a percepção desta notoriedade e a fácil visualização destes dados. 


\section{CONSIDERAÇÕES FINAIS}

O Brasil contém em sua gestão um instrumento de suma importância ao seu cenário governamental, o GesPública. Este Programa permite aos órgãos federais a busca pela qualidade, isto é sentido pela sociedade como um todo que reconhece e apóia as atitudes que busquem suas expectativas.

O órgão brasileiro oficial de turismo, o Ministério do Turismo, não está obviamente praticando os conceitos do Programa Nacional de Gestão Pública e Desburocratização. No entanto, o mesmo tenta atingir seus objetivos de maneira razoável de gestão, porém, os elementos administrativos explorados e expostos em documentos oficiais não se assemelham àqueles citados pela administração contemporânea de alcance sistêmico da atividade exercida, o Turismo.

Apesar disto, o Ministério possui dois artifícios que demonstram a preocupação dessa entidade em conhecer a cadeia atingida através de suas normalizações ou propostas ao turismo nacional. O Conselho Nacional de Turismo, composto por associações do trade e o Fórum Nacional dos Secretários e Dirigentes Estaduais de Turismo permitem ao MTUR não só a ciência de fenômenos ocorridos no País como também, a troca de experiências em diversas localidades e culturas.

O turismo brasileiro, contudo, poderia ganhar muito mais com relação ao desenvolvimento e aos resultados se adotasse o GESPÚBLICA. Não somente por sua visão interna organizacional, mas principalmente externa e sempre em busca da excelência, uma vez que esta é inalcançável.

A qualidade nesse órgão, assim como em outros onde houve uma sistematização da qualidade e a aplicação do Programa deve ser alcançada a partir da participação efetiva não somente da sociedade como também dos cidadãos, dos indivíduos que compõem esta sociedade. Alguns autores colocam que quem padroniza a qualidade é o público alvo, portanto a plena informação do cliente externo é extremamente necessária como fonte alimentar do ponto a ser observado.

A aplicação do método de processos é de todos os critérios do GESPÚBLICA, aquele que permite e viabiliza de fato a diminuição dos excessos burocráticos existentes nas entidades 
públicas. No órgão de turismo, certamente, esta abordagem é correta e necessária para almejar as metas e objetivos do Ministério de maneira rápida e de visualização e valorização nacional. Por fim, a gestão do turismo brasileiro seria projetada e executada de maneira sistêmica e, aquém de direito. O turismo deve para seu verdadeiro desenvolvimento nacional caminhar de forma sistêmica, ou seja, ele tem de estar a par de quem atinge e como este meio influencia em suas ações. 


\section{REFERÊNCIAS}

ALGARTE, Waldir; QUINTANILHA, Delma. A História da Qualidade e o Programa Brasileiro da Qualidade e Produtividade. Rio de Janeiro: INMETRO/ SENAI, 2000.

BARRETO, Margarida. Introdução ao Turismo. São Paulo: Papirus, 1995.

CAMARGO, Haroldo Leitão. Uma Pré História do Turismo no Brasil: recreações aristocráticas e lazeres burgueses (1808 - 1850). São Paulo: Aleph, 2007. (Série Turismo).

DIAS, Reinaldo. Introdução ao Turismo. São Paulo: Atlas, 2008.

EMBRATUR; MTUR. Chegadas de Turistas ao Brasil 1970-2007 in Anuário Estatístico

Embratur. V. 35, 2008. Disponível em www.turismo.gov.br/dadosefatos, acesso em 06 de abril de 2009.

LAGE, Beatriz Helena Gelas; MILONE, Paulo César (organizadores). Turismo: Teoria e Prática. São Paulo: Atlas, 2000.

LIMA, Paulo Daniel Barreto. Excelência em Gestão Pública: a trajetória e a estratégica do gespública. Rio de Janeiro: Qualitymark, 2007.

MARANHÃO, Mauriti; MACIEIRA, Maria Helena Bastos. O processo nosso de cada dia: modelagem de processos de trabalho. Rio de Janeiro: Qualitymark, 2004.

MARCONI, Marina de Andrade; LAKATOS, Eva Maria. Fundamentos de metodologia Científica. 6.ed.. São Paulo: Atlas, 2005.

MINISTÉRIO DO PLANEJAMENTO, ORÇAMENTO E GESTÃO. Gestão. Disponível em www.planejamento.gov.br, acesso dia 05 de maio de 2009.

MINISTÉRIO DO PLANEJAMENTO, ORÇAMENTO E GESTÃO; CONSELHO NACIONAL DE SECRETÁRIOS ESTADUA̧IS DE ADMINISTRAÇÃO. Carta de Brasília: Gestão Pública. Brasília: MP, SEGES, 2008.

MINISTÉRIO DO PLANEJAMENTO, ORÇAMENTO E GESTÃO; SECRETARIA DE GESTÃO. Documento de Referencia: Gespública disponível em www.gespublica.gov.br, acesso dia 05 de maio de 2009, p. 09.

MINISTÉRIO DO PLANEJAMENTO, ORÇAMENTO E GESTÃO; SECRETARIA DE GESTÃO. Gespública Documento de Referencia 2008/2009. Brasília: MP, SEGES, 2009.

MINISTÉRIO DO PLANEJAMENTO, ORÇAMENTO E GESTÃO; SECRETARIA DE GESTÃO. Guia D simplificação. Brasília: MP, SEGES, 2005.

MINISTÉRIO DO PLANEJAMENTO, ORÇAMENTO E GESTÃO; SECRETARIA DE GESTÃO. Instrumento para Avaliação da Gestão Pública - 2008/2009. Versão 1/2008. Brasília: MP, SEGES, 2008.

MINISTÉRIO DO PLANEJAMENTO, ORÇAMENTO E GESTÃO; SECRETARIA DE GESTÃO. Relatório de Atividades de 2008 da Secretaria de Gestão 2008. Disponível em http://www.planejamento.gov.br/secretarias, acesso 04 de maio de 2009.

MINISTÉRIO DO TURISMO. Boletim de Desempenho Econômico do Turismo. Janeiro de 2009. Ano VI. Número 21. Disponível em www.turismo.gov.br/dadosefatos, acesso em 08 de abril de 2009. 
MINISTÉRIO DO TURISMO. Estrutura Organizacional do Ministério. Disponível em www.turismo.gov.br/dadosefatos, acesso em 09 de maio de 2009.

MINISTÉRIO DO TURISMO. Plano Nacional de Turismo 2007/2010: Uma Viagem de Inclusão. Brasília. MTUR, 2007.

MINISTÉRIO DO TURISMO. Turismo no Brasil: 2007-2010. Brasília: MTUR; CNT, 2006.

ORGANIZAÇÃO MUNDIAL DO TURISMO (O.M.T.). Introdução ao Turismo. Direção e Redação Amparo Sancho; Traduzido por Dolores Martin Rodriguez Corner. São Paulo: Roca, 2001.

ORGANIZAÇÃO MUNDIAL DE TURISMO. UNWTO News: Magazine of the World Tourism Organization. Ano XXIII. Edição 1/2009. Disponível em www.unwto.org, acesso em 08 de abril de 2009.

REJOWSKI, Miriam (organizadora). Turismo no percurso do tempo. São Paulo: Aleph, 2002.

RUCHMANN, Doris van de Meene. Turismo e Planejamento Sustentável: A Proteção do Meio Ambiente. 10 ed.. Campinas, SP: Papirus, 2003 - (Coleção Turismo).

SCHLUTER, Regina G.. Metodologia da Pesquisa em Turismo e Hotelaria (Série Turismo). São Paulo: Aleph, 2003.

TRIGO, Luiz Gonzaga Godoi. Turismo Básico. 6. ed. ver. ampl.. São Paulo: Senac, 2002.

VIERA, Elenara Viera de; CÂNDIDO, Índio. Glossário Técnico: gastronômico, hoteleiro e turístico. Caxias do Sul: Educs, 2003.

YOUELL, Ray. Turismo: Uma Introdução. São Paulo: Contexto, 2002. 


\section{ANEXOS \\ Anexo A: Competências dos Departamentos do Ministério do Turismo ${ }^{33}$}

\subsection{Assessoria de Comunicação Social do Ministério do Turismo}

I. planejar, orientar, controlar e supervisionar a execução das atividades de comunicação social do Ministério, de unidades descentralizadas e de entidade a ele vinculada, observadas as diretrizes do órgão responsável pela Comunicação Social da Presidência da República;

II. subsidiar a definição de estratégias de divulgação das ações e serviços do Ministério;

III. coordenar a execução das ações de publicidade institucional e legal do Ministério, bem como a editoração e as publicações técnicas e institucionais;

IV. acompanhar, junto à mídia em geral, a formação de opinião pública relativa ao Ministério e seus órgãos;

V. coordenar e acompanhar as atividades administrativas da Assessoria;

VI. acompanhar a editoração das publicações técnicas e institucionais do Ministério;

VII. solicitar a aquisição e controlar a distribuição de jornais, revistas e periódicos, de natureza geral e técnica, em conformidade com as determinações específicas do órgão normatizador;

VIII. analisar e acompanhar a contratação de agências de publicidade e a realização de campanhas publicitárias institucionais e de serviços;

IX. receber, avaliar e acompanhar a demanda de serviços de edição das publicações técnicas e institucionais do Ministério;

$\mathrm{X}$. executar as atividades relativas à aquisição e distribuição de periódicos, de natureza geral e técnica, às unidades do Ministério;

XI. pesquisar, selecionar e analisar matérias e notícias divulgadas na mídia relativas ao Ministério, ou de seu interesse, com vistas ao acompanhamento da opinião pública;

XII. organizar e manter arquivo de assuntos de interesse do Ministério captados na imprensa;

XIII. promover a articulação do Ministério com a mídia em geral, com vistas à divulgação das ações da Pasta;

XIV. copidescar textos jornalísticos e técnicos destinados a informar e orientar a mídia e o público com relação às atividades do Ministério;

XV. produzir e divulgar as publicações editadas pela Assessoria de Comunicação Social.

\subsection{Assessoria Parlamentar do Ministério do Turismo}

I. supervisionar, orientar e controlar as atividades relacionadas ao acompanhamento de matérias legislativas e outros assuntos de interesse do Ministério junto ao Poder Legislativo;

\footnotetext{
${ }^{33}$ Legislação disponível no site, www.turismo.gov.br acesso dia 09 de maio de 2009.
} 
II. solicitar às áreas técnicas do Ministério parecer sobre os projetos de lei de interesse do Ministério em tramitação no Poder Legislativo;

III. analisar, compatibilizar e providenciar o encaminhamento de pareceres à Presidência da República ou às lideranças do Governo na Câmara dos Deputados, no Senado Federal e no Congresso Nacional;

IV. providenciar o atendimento aos Requerimentos de Informações do Poder Legislativo em articulação com os demais órgãos do Ministério, respeitando os prazos legais;

V. submeter aos órgãos técnicos os pleitos de informação de parlamentares e providenciar o respectivo atendimento;

VI. preparar, consultando os órgãos técnicos, o posicionamento conclusivo do Ministério sobre matérias de seu interesse em fase de sanção presidencial, indicando as razões de veto ou de apoio;

VII. examinar e compatibilizar os subsídios fornecidos pelos órgãos técnicos chamados a opinar sobre as proposições legislativas ou pleitos de parlamentares;

VIII. realizar estudos e análises sobre a ação parlamentar;

IX. acompanhar e manter atualizados os pronunciamentos parlamentares sobre assuntos da área de competência do Ministério;

$\mathrm{X}$. desenvolver e manter atualizado arquivo sobre o perfil dos parlamentares;

XI. acompanhar e manter atualizadas as proposições legislativas de interesse do Ministério e de Requerimentos de Informações;

XII. elaborar relatórios sobre o andamento de projetos de lei, pleitos e pronunciamentos dos parlamentares;

XIII. providenciar a interligação dos serviços informatizados da Assessoria Parlamentar com outros congêneres;

XIV. examinar e propor alternativas que permitam a racionalização e o melhor aproveitamento dos sistemas de informações disponíveis;

$\mathrm{XV}$. acompanhar o andamento de matérias, proposições e pronunciamentos de interesse do Ministério, em plenário, comissões permanentes e comissões especiais;

XVI. providenciar o encaminhamento de documentos de interesse do Ministério, gerados na Câmara dos Deputados, no Senado Federal e do Congresso Nacional, às respectivas áreas técnicas;

XVII. encaminhar solicitações de Deputados e de Senadores, prestar-lhes esclarecimentos e informações sobre matérias de competência do Ministério;

XVIII. manter os contatos necessários ao bom andamento das matérias de interesse do Ministério em tramitação na Câmara dos Deputados, no Senado Federal e no Congresso Nacional;

XIX. acompanhar as autoridades do Ministério em visitas e audiências na Câmara dos Deputados, no Senado Federal e no Congresso Nacional, prestando-lhes o apoio necessário;

$\mathrm{XX}$. elaborar súmulas e análises diárias sobre as atividades legislativas e parlamentares de interesse do Ministério;

XXI. informar às Bancadas Parlamentares da presença do Ministro de Estado nas respectivas regiões. 


\subsection{Assessoria Internacional do Ministério do Turismo}

I. planejar e coordenar a execução de programas e ações vinculados à área internacional;

II. fornecer informações relativas ao acompanhamento das ações e programas do Plano Plurianual no âmbito da Assessoria Internacional;

III. promover a articulação das ações e programas em desenvolvimento no âmbito da área internacional do Ministério;

IV. coordenar as atividades relativas à administração de pessoal da Assessoria Internacional;

V. elaborar os relatórios sobre convenções e recomendações da OMT, bem como responder aos questionamentos formulados pelos órgãos de controle da referida organização e outros organismos internacionais;

VI. levantar dados que subsidiem a elaboração dos relatórios sobre as convenções da OMT e outros organismos internacionais;

VII. acompanhar, em conjunto com a Assessoria Parlamentar, a tramitação no Congresso Nacional de expedientes relativos à área internacional;

VIII. manter os órgãos técnicos do Ministério informados sobre os assuntos relativos à OMT e outros organismos e entidades internacionais;

IX. coordenar a consulta sobre temas da agenda internacional junto às representações de turismo; X. coordenar a elaboração e edição de publicações relacionadas às ações, atividades e aos programas da agenda internacional do Ministério e de organismos e entidades internacionais;

XI. representar o Ministério em conselhos, comissões e fóruns nacionais e internacionais vinculados ou relativos a organismos internacionais;

XII. acompanhar o desenvolvimento de programas e atividades realizados por organismos e entidades internacionais, analisando as possibilidades de vinculação desses com áreas de competência do Ministério;

XIII. propor, viabilizar e acompanhar atividades e programas de cooperação e intercâmbio com governos estrangeiros, organismos e entidades internacionais;

XIV. colaborar com as áreas técnicas do Ministério no planejamento, na organização e realização de eventos de caráter internacional realizados no país;

XV. divulgar eventos de caráter internacional;

XVI. emitir parecer técnico quanto à viabilidade e oportunidade da participação de servidores do Ministério em cursos, palestras, seminários e outros eventos de âmbito internacional;

XVII. analisar e adotar as previdências necessárias para a participação de servidores do Ministério em programas de pós-graduação no exterior, cursos, palestras e outros eventos internacionais;

XVIII. manter registro da participação de representantes do Ministério em eventos no exterior;

XIX. acompanhar, junto às diversas áreas do Ministério das Relações Exteriores, os assuntos relativos à área de competência do Ministério; 
XX. participar de seminários e reuniões dos Comitês Nacionais que visem à preparação da participação do Brasil em cúpulas e conferências internacionais da Organização das Nações Unidas (ONU);

XXI. receber, identificar, registrar, classificar, encaminhar, organizar e controlar todo o acervo documental da Assessoria Internacional;

XXII. executar as atividades de administração de material, patrimônio e serviços gerais da Assessoria Internacional;

XXIII. acompanhar atividades de editoração eletrônica e reprografia de materiais relacionados à área internacional;

XXIV. providenciar a solicitação de passagens e diárias dos servidores da Assessoria;

XXV. providenciar apoio logístico necessário ao funcionamento da Assessoria;

XXVI. planejar, orientar, supervisionar e acompanhar os temas relacionados à área internacional de interesse do Ministério e, especificamente:

XXVII. subsidiar o Ministro de Estado na elaboração da política internacional dos assuntos de competência técnica do Ministério, observando a política externa brasileira;

XXVIII. coordenar e apoiar a participação de representantes do Ministério em fóruns, organismos e entidades internacionais vinculados à sua área de competência;

XXIX. conduzir assuntos pertinentes a organismos e fóruns internacionais, entidades e governos estrangeiros, em temas de interesse do Ministério;

XXX. coordenar e supervisionar as atividades de caráter internacional, em articulação com os demais órgãos do Ministério, em estrita observância aos ditames da política externa brasileira;

XXXI. providenciar a tradução de expedientes de origem estrangeira do Gabinete.

\subsection{Ouvidoria do Ministério do Turismo}

I. propor, coordenar e implementar a Plano Nacional do Turismo, buscando integrar e estimular práticas que ampliem o acesso dos usuários ao processo de divulgação do turismo brasileiro;

II. estimular e apoiar a criação de estruturas descentralizadas do turismo;

III. implementar políticas de estímulo à participação de usuários e entidades da sociedade no processo de avaliação dos serviços prestados pelos organismos promotores do turismo;

IV. analisar sugestões emanadas da sociedade civil por intermédio de suas organizações, com vistas à ampliação do acesso e à melhoria dos serviços de turismo e promover a discussão com os outros órgãos do Ministério;

V. estimular a realização permanente de fóruns de usuários de turismo;

VI. promover ações para assegurar a preservação dos aspectos éticos, de privacidade e confidencialidade em todas as etapas do processamento das reclamações ou informações decorrentes;

VII. propor medidas visando assegurar o acesso do cidadão às informações individuais existentes nos órgãos de turismo;

VIII. recomendar a correção de problemas identificados mediante reclamações enviadas diretamente ao Ministério contra atos e omissões ilegais ou indevidas no âmbito do turismo; 
IX. recomendar a revogação ou correção de atos que não atendam aos objetivos e normas constantes da legislação vigente na área do turismo.

\subsection{Gabinete da Secretaria-Executiva}

I. assistir o Secretário-Executivo na execução de suas atribuições;

II. coordenar a pauta de trabalho do Secretário-Executivo e solicitar o preparo de expediente para seu despacho;

III. orientar e controlar as atividades administrativas no âmbito do Gabinete da SecretariaExecutiva;

IV. assessorar o Secretário-Executivo na coordenação do processo de planejamento estratégico institucional e na supervisão e avaliação do mesmo;

V. assistir o Secretário-Executivo na supervisão e coordenação da ação institucional.

\subsection{Subsecretaria de Planejamento, Orçamento e Administração}

I. planejar, coordenar e supervisionar, no âmbito do Ministério, a execução das atividades de organização e modernização administrativa, bem como as relacionadas com os sistemas federais de planejamento e de orçamento, de administração financeira, de contabilidade, de administração dos recursos de informação e informática, de pessoal civil e de serviços gerais;

II. promover a articulação com os órgãos centrais dos sistemas federais, referidos no inciso I e informar e orientar os órgãos e entidade do Ministério quanto ao cumprimento das normas administrativas estabelecidas;

III. promover e coordenar a elaboração e consolidação dos planos e programas das atividades de sua área de competência e submetê-los à decisão superior;

IV. desenvolver as atividades de execução orçamentária, financeira e contábil no âmbito do Ministério;

V. analisar e avaliar as prestações de contas, parciais ou finais, quanto aos seus aspectos técnicos e financeiros, propondo a instauração de tomada de contas especial e demais medidas de sua competência quando a prestação de contas não for aprovada, após exauridas as providências cabíveis;

VI. realizar tomadas de contas dos ordenadores de despesas e demais responsáveis por bens e valores públicos e de todo aquele que der causa a perda, extravio ou outra irregularidade que resulte em dano ao erário.

\subsection{Departamento de Infra-Estrutura do Ministério do Turismo}

I. formular, coordenar e acompanhar os planos, programas e ações do Ministério voltados à implementação de projetos de infra-estrutura turística;

II. coordenar, fiscalizar, acompanhar e avaliar a aplicação de recursos de responsabilidade do Ministério em projetos de infra-estrutura turística;

III. apoiar a formulação de propostas de recuperação de patrimônio histórico integrante de produto turístico estruturado ou em estruturação; 
IV. analisar investimento em saneamento básico e ambiental integrante de projeto turístico estruturado ou em estruturação, em conformidade com a Política Nacional de Turismo;

V. articular com os demais órgãos governamentais e entidades da Administração Federal, Estadual e Municipal em seus programas, projetos e ações de infra-estrutura que interagem com a Política Nacional de Turismo.

\subsection{Departamento de Financiamento e Promoção de Investimentos no Turismo}

I. coordenar o estabelecimento de diretrizes e prioridades para a aplicação dos recursos do Fundo Geral de Turismo (FUNGETUR);

II. coordenar a formulação, apoiar e acompanhar as ações de estímulo e fomento à mobilização da iniciativa privada, nacional e internacional, para a sua participação ativa na implementação da Política Nacional de Turismo;

III. coordenar, apoiar e acompanhar o desenvolvimento de planos, projetos e eventos que objetivem a captação e estímulo aos investimentos nacionais e internacionais, em ações integradas com as diretrizes e nas regiões beneficiadas pelos programas de desenvolvimento do turismo;

IV. coordenar, apoiar e acompanhar o desenvolvimento, a manutenção e a promoção de projetos e de oportunidades de investimentos;

V. coordenar, apoiar e acompanhar o desenvolvimento, junto às instituições financeiras de linhas de crédito e outros instrumentos financeiros, voltados para o financiamento ao turista e às empresas da cadeia produtiva do turismo;

VI. coordenar e acompanhar a integração das ações de sua competência com a EMBRATUR;

VII. orientar, acompanhar e supervisionar a execução dos projetos e programas de financiamento de obras, serviços e atividades turísticas no âmbito do FUNGETUR;

VIII. elaborar estudos com vistas à uniformização de normas e procedimentos operacionais do FUNGETUR;

IX. acompanhar e propor, quando necessário, ajustes na regulamentação do FUNGETUR;

$\mathrm{X}$. propor convênios ou contratos a serem celebrados com os bancos de desenvolvimento e de investimento e com as demais instituições financeiras, em conformidade com regulamento específico;

XI. elaborar relatórios e exercer os controles das operações financeiras realizadas no âmbito da gestão do FUNGETUR.

\subsection{Departamento de Programas Regionais de Desenvolvimento do Turismo}

I. coordenar a formulação, apoiar e acompanhar os programas regionais de desenvolvimento do turismo, que objetivem beneficiar as populações locais e o incremento da renda gerada pelo turismo nacional e internacional;

II. subsidiar a formulação, coordenar, apoiar e acompanhar a promoção do apoio técnico, institucional e financeiro necessário ao fortalecimento da execução e participação dos estados, do Distrito Federal e dos municípios, nestes programas;

III. coordenar a formulação, apoiar e acompanhar a estrutura institucional e financeira adequada para a execução dos programas regionais de desenvolvimento do turismo; 
IV. coordenar a formulação, apoiar e acompanhar o aporte de recursos de responsabilidade do Ministério, em conformidade com as diretrizes e a matriz de financiamento de cada programa;

V. coordenar e acompanhar a integração das ações de sua competência com a EMBRATUR.

\subsection{Departamento de Qualificação e Certificação e de Produção e Associada ao Turismo}

I. formatar, implementar e apoiar os planos, programas e ações voltados ao desenvolvimento da produção artesanal e demais produtos associados ao turismo;

II. coordenar as ações voltadas para a promoção e comercialização da produção artesanal e demais produtos associados ao turismo;

III. formatar e implementar os programas e ações voltadas ao desenvolvimento da qualificação e certificação de profissionais, de equipamentos e serviços turísticos;

IV. coordenar as ações voltadas à qualificação profissional e à melhoria da qualidade dos serviços prestados ao turista;

V. desenvolver, implementar e apoiar projetos estruturantes, em regiões alvo de novos investimentos turísticos geradores de impactos econômicos e sociais;

VI. articular, apoiar e acompanhar a promoção de apoio técnico, institucional e financeiro necessários às regiões com potencial turístico e de baixa renda per capita, em conformidade com o Plano Nacional de Turismo;

VII. coordenar a formulação, apoiar e acompanhar os planos, programas e ações voltados para a geração de novas alternativas de desenvolvimento local com base nos segmentos turísticos e sua cadeia produtiva, de acordo com a Política Nacional de Turismo;

VIII. articular com os demais órgãos e entidades da Administração Federal, Estadual, Municipal, do setor produtivo e terceiro setor, programas, projetos e ações que tenham interface com o Departamento.

\subsection{Departamento de Planejamento e Avaliação do Turismo}

I. planejar, coordenar, acompanhar e avaliar a Política Nacional de Turismo;

II. coordenar a elaboração e avaliação do Plano Nacional de Turismo;

III. elaborar os instrumentos e normas destinados à implementação da Política Nacional de Turismo;

IV. realizar estudos, pesquisas, análises e levantamentos de dados e indicadores necessários à formulação, implementação e avaliação da Política Nacional de Turismo;

V. acompanhar a dinâmica do mercado turístico nacional e internacional com vistas a subsidiar a formulação e avaliação da Política Nacional de Turismo;

VI. prestar apoio técnico e administrativo ao Conselho Nacional de Turismo;

VII. acompanhar a gestão descentralizada do Plano Nacional de Turismo nas ações dos conselhos e fóruns estaduais, regionais e municipais;

VIII. promover a coordenação e interação entre o Secretário-Executivo e o Conselho Nacional de Turismo, bem como a coordenação operacional do mesmo; 
IX. coordenar, acompanhar e avaliar a Política Nacional de Turismo, assegurando a coerência entre as diretrizes governamentais e as políticas públicas que integram o Plano Plurianual do Governo Federal;

X. coordenar, acompanhar e avaliar o Plano Nacional de Turismo, assegurando a integração entre os programas e ações priorizados através dos Macroprogramas;

XI. implementar atividades de monitoramento e avaliação da Política Nacional de Turismo, através de Sistemas e Redes de informações gerenciais, técnicas e políticas;

XII. coordenar a definição, construção e implementação do Sistema de Monitoramento do Plano Nacional de Turismo;

XIII. propor, formatar e apoiar a realização de estudos, pesquisas, levantamentos de dados e indicadores com vistas ao monitoramento e aperfeiçoamento do processo de planejamento do Plano Nacional de Turismo;

XIV. disponibilizar informações gerenciais, técnicas e políticas sobre o modelo descentralizado do turismo, dando suporte ao processo decisório do MTur;

XV. realizar ações de sensibilização e conscientização da Política Nacional de Turismo junto aos Fóruns/Conselhos Estaduais, Regionais e Municipais, as Universidades, Secretarias Estaduais de Turismo e outras instituições de interesse do setor;

XVI. coordenar a estrutura de articuladores e/ou consultores no MTur e interlocutores nas unidades da Federação, para garantir a construção eficiente do modelo descentralizado dos 27 Fóruns/Conselhos Estaduais de Turismo;

XVII. coordenar a gestão institucional e a ação de relatoria das oito Câmaras Temáticas identificadas para o fortalecimento da Política Nacional de Turismo;

XVIII. coordenar a gestão do Fórum Nacional de Secretários de Turismo no que se refere ao Plano Nacional de Turismo;

XIX. coordenar a Câmara Temática de Qualificação da Superestrutura do Turismo fortalecendo o interrelacionamento institucional público e privado para o desenvolvimento do turismo;

XX. coordenar a Execução Programática versus Orçamentária no âmbito do Plano Nacional de Turismo;

XXI. aprovar de Políticas e encaminhar os Relatórios de Atividades e Relatórios Gerenciais para a Secretaria Nacional e Departamentos do Ministério do Turismo;

XXII. aprovar e encaminhar os pareceres técnicos demandados pela Secretaria Nacional de Políticas do Turismo;

XXIII. coordenar reuniões quinzenais de Diretores, no âmbito do Ministério do Turismo, para integração dos Departamentos;

XXIV. participar dos eventos de interesse do turismo nacional, realizando ações institucionais programáticas na área da competência do DPAT;

XXV. apoiar a estruturação de um Centro de Documentação e Referência para congregar e disponibilizar a produção técnica e as informações de interesse do Ministério do Turismo.

\subsection{Departamento de Estruturação, Articulação e Ordenamento Turístico}


I - coordenar, acompanhar supervisionar e articular políticas, planos, programas, projetos e ações para a estruturação e diversificação da oferta turística;

II - coordenar e exercer a cooperação e a articulação com os órgãos da Administração Federal, Estadual, do Distrito Federal, Municipal e entidades não-governamentais em programas projetos e ações de fiscalização, classificação e cadastramento de serviços e empreendimentos turísticos e de outros que tenham interface com os projetos, programas e ações do Departamento;

III - apoiar o planejamento de programas e projetos no âmbito da Administração dos Estados, Distrito Federal, de Municípios e de micro-regiões que contribuam para o fortalecimento e desenvolvimento sustentável da atividade turística;

IV - subsidiar a formulação e o gerenciamento de políticas, planos, programas e projetos para o ordenamento e desenvolvimento do turismo e de seus segmentos no âmbito local, regional, estadual e nacional, promovendo a inserção da temática social, ambiental e cultural;

V - subsidiar a formulação de políticas, atos normativos, regulamentários e de físcalização para o ordenamento e a qualificação dos serviços turísticos e da atividade turística em geral; e

VI - criar e gerenciar instrumentos e mecanismos de comunicação, estabelecendo redes de informação e relacionamentos para subsidiar a implantação do Plano Nacional do Turismo e fortalecer a atividade turística.

\subsection{Departamento de Promoção e Marketing Nacional do Ministério do Turismo}

I. propor, apoiar, planejar, coordenar e acompanhar as ações e projetos de marketing, promoção, propaganda e divulgação do turismo brasileiro no mercado nacional;

II. apoiar, planejar, coordenar e acompanhar os programas de promoção e divulgação de eventos e dos produtos turísticos brasileiros no mercado nacional;

III. apoiar, planejar, coordenar e acompanhar a promoção e divulgação de produtos associados ao turismo no mercado nacional;

IV. articular e interagir com os demais órgãos da Administração Federal, em especial com a Secretaria de Comunicação de Governo e Gestão Estratégica, conforme estabelecido no Decreto no 4.799, de 4 de agosto de 2003.

\subsection{Departamento de Relações Internacionais do Turismo}

I. apoiar, planejar, coordenar e acompanhar a celebração de acordos e instrumentos de cooperação técnica internacional;

II. apoiar, planejar, coordenar e acompanhar a atuação e participação do Ministério do Turismo em fóruns e organismos internacionais de interesse do turismo nacional;

III. apoiar, planejar, coordenar e acompanhar a atuação do Ministério nas negociações de acordos comerciais bilaterais, regionais e multilaterais, com fins do fortalecimento do turismo nacional no cenário internacional;

IV. apoiar, planejar, coordenar e acompanhar a articulação com os demais órgãos e instituições governamentais com atuação no cenário internacional;

V. pesquisar, prospectar e atrair novas tecnologias, conhecimentos e oportunidades no mercado internacional. 


\section{Anexo B: Decreto No5378 de 23 de fevereiro de 2005, Gespública ${ }^{34}$.}

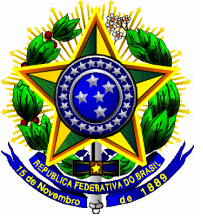

DECRETO N 5.378 DE 23 DE FEVEREIRO DE 2005.

\section{Presidência da República}

Casa Civil

Subchefia para Assuntos Jurídicos
Institui o Programa Nacional de Gestão Pública e Desburocratização - GESPÚBLICA e o Comitê Gestor do Programa Nacional de Gestão Pública e Desburocratização, e dá outras providências.

O PRESIDENTE DA REPÚBLICA, no uso da atribuição que lhe confere o art. 84, inciso VI, alínea "a", da Constituição,

\section{DECRETA:}

Art. 1ํ Fica instituído o Programa Nacional de Gestão Pública e Desburocratização GESPÚBLICA, com a finalidade de contribuir para a melhoria da qualidade dos serviços públicos prestados aos cidadãos e para o aumento da competitividade do País.

Art. $2^{\circ}$ O GESPÚBLICA deverá contemplar a formulação e implementação de medidas integradas em agenda de transformações da gestão, necessárias à promoção dos resultados preconizados no plano plurianual, à consolidação da administração pública profissional voltada ao interesse do cidadão e à aplicação de instrumentos e abordagens gerenciais, que objetivem:

I - eliminar o déficit institucional, visando ao integral atendimento das competências constitucionais do Poder Executivo Federal;

II - promover a governança, aumentando a capacidade de formulação, implementação e avaliação das políticas públicas;

III - promover a eficiência, por meio de melhor aproveitamento dos recursos, relativamente aos resultados da ação pública;

IV - assegurar a eficácia e efetividade da ação governamental, promovendo a adequação entre meios, ações, impactos e resultados; e

$\mathrm{V}$ - promover a gestão democrática, participativa, transparente e ética.

Art. $3^{\circ}$ Para consecução do disposto nos arts. $1^{\circ}$ e $2^{-}$, o GESPÚBLICA, por meio do Comitê Gestor de que trata o art. $7^{\circ}$, deverá:

I - mobilizar os órgãos e entidades da administração pública para a melhoria da gestão e para a desburocratização;

II - apoiar tecnicamente os órgãos e entidades da administração pública na melhoria do atendimento ao cidadão e na simplificação de procedimentos e normas;

III - orientar e capacitar os órgãos e entidades da administração publica para a implantação de ciclos contínuos de avaliação e de melhoria da gestão; e

\footnotetext{
${ }^{34}$ Disponível em www.gespublica.gov.br .
} 
IV - desenvolver modelo de excelência em gestão pública, fixando parâmetros e critérios para a avaliação e melhoria da qualidade da gestão pública, da capacidade de atendimento ao cidadão e da eficiência e eficácia dos atos da administração pública federal.

Art. $4^{\circ}$ Os critérios para avaliação da gestão de que trata este Decreto serão estabelecidos em consonância com o modelo de excelência em gestão pública.

Art. $5^{\circ}$ A participação dos órgãos e entidades da administração pública no GESPÚBLICA dar-se-á mediante adesão ou convocação.

$\S 1^{\circ}$ Considera-se adesão para os efeitos deste Decreto o engajamento voluntário do órgão ou entidade da administração pública no alcance da finalidade do GESPÚBLICA, que, por meio da auto-avaliação contínua, obtenha validação dos resultados da sua gestão.

$\S 2^{0}$ Considera-se convocação a assinatura por órgão ou entidade da administração pública direta, autárquica ou fundacional, em decorrência da legislação aplicável, de contrato de gestão ou desempenho, ou o engajamento no GESPÚBLICA, por solicitação do Ministro de Estado do Planejamento, Orçamento e Gestão, em decorrência do exercício de competências vinculadas a programas prioritários, definidos pelo Presidente da República.

Art. $6^{\circ}$ Poderão participar, voluntariamente, das ações do GESPÚBLICA pessoas e organizações, públicas ou privadas.

Parágrafo único. A atuação voluntária das pessoas é considerada serviço público relevante, não remunerado.

Art. $7^{0}$ Fica instituído o Comitê Gestor do Programa Nacional de Gestão Pública e Desburocratização, no âmbito do Ministério do Planejamento, Orçamento e Gestão, com o objetivo de formular o planejamento das ações do GESPÚBLICA, bem como coordenar e avaliar a execução dessas ações.

Art. $8^{\circ}$ O Comitê Gestor terá a seguinte composição:

I - um representante do Ministério do Planejamento, Orçamento e Gestão, que o coordenará; e

II - um representante da Casa Civil da Presidência da República.

$\S 1^{\text {o }}$ O Ministro de Estado do Planejamento, Orçamento e Gestão indicará quinze órgãos ou entidades da administração pública, com notório engajamento em ações ligadas à qualidade da gestão e à desburocratização, cujos representantes integrarão o Comitê Gestor.

$\S 2^{0}$ Os membros a que se referem o caput e o $\S 1^{\circ}$, titulares e suplentes, serão indicados pelos dirigentes dos órgãos ou entidades representados e designados pelo Ministro de Estado do Planejamento, Orçamento e Gestão.

$\S 3^{0}$ O mandato dos membros do Comitê Gestor será de dois anos, permitida a recondução.

Art. 9ํㅜ Ao Comitê Gestor compete:

I - propor ao Ministro de Estado do Planejamento, Orçamento e Gestão o planejamento estratégico do GESPÚBLICA;

II - articular-se para a identificação de mecanismos que possibilitem a obtenção de recursos e demais meios para a execução das ações do GESPÚBLICA;

III - constituir comissões setoriais e regionais, com a finalidade de descentralizar a gestão do GESPÚBLICA;

IV - monitorar, avaliar e divulgar os resultados do GESPÚBLICA; 
V - certificar a validação dos resultados da auto-avaliação dos órgãos e entidades participantes do GESPÚBLICA; e

VI - reconhecer e premiar os órgãos e entidades da administração pública, participantes do GESPÚBLICA, que demonstrem qualidade em gestão, medida pelos resultados institucionais obtidos.

Art. 10. Ao Coordenador do Comitê Gestor compete:

I - cumprir e fazer cumprir este Decreto e as decisões do Colegiado;

II - constituir grupos de trabalho temáticos temporários;

III - convocar e coordenar as reuniões do Comitê; e

IV - exercer o voto de qualidade no caso de empate nas deliberações.

Art. 11. A participação nas atividades do Comitê Gestor, das comissões e dos grupos de trabalho será considerada serviço público relevante, não remunerado.

Art. 12. A Secretaria de Gestão do Ministério do Planejamento, Orçamento e Gestão exercerá as funções de Secretaria-Executiva do Comitê Gestor.

Art. 13. Este Decreto entra em vigor na data de sua publicação.

Art. 14. Ficam revogados os Decretos $n^{\text {os }} 83.740$, de 18 de julho de 1979 , e 3.335, de 11 de janeiro de 2000.

Brasília, 23 de fevereiro de 2005; $184^{\circ}$ da Independência e $117^{\circ}$ da República.

LUIZ INÁCIO LULA DA SILVA

Nelson Machado

José Dirceu de Oliveira e Silva

\title{
Anexo C: Decreto de 17 de março de 2009, Ano Nacional da Gestão Pública ${ }^{35}$.
}

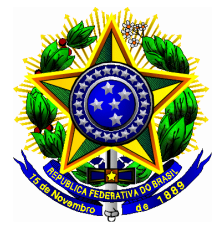

\author{
Presidência da República \\ Casa Civil \\ Subchefia para Assuntos Jurídicos
}

DECRETO DE 17 DE MARCO DE 2009.

Institui o ano de 2009 como "Ano Nacional da Gestão Pública”.

O PRESIDENTE DA REPÚBLICA, no uso da atribuição que lhe confere o art. 84, inciso VI, alínea "a", da Constituição,

\section{DECRETA:}

\footnotetext{
${ }^{35}$ Disponível em www.gespublica.gov.br.
} 
Art. $1^{\text {o }}$ Fica instituído o ano de 2009 como “Ano Nacional da Gestão Pública”.

Art. $2^{\underline{0}}$ Este Decreto entra em vigor na data de sua publicação.

Brasília, 17 de março de 2009; $188^{\circ}$ da Independência e $121^{\circ}$ da República.

LUIZ INÁCIO LULA DA SILVA

Paulo Bernardo Silva

\section{Anexo D: Carta de Brasília ${ }^{36}$}

\section{Carta de Brasília}

Carta de Brasília sobre Gestão Pública

Carta conjunta do Ministério do Planejamento, Orçamento e Gestão e do Conselho Nacional de Secretários Estaduais de Administração - CONSAD por ocasião do Congresso do CONSAD

Congresso CONSAD de Gestão Pública

26 a 28 de maio de 2008 - Brasília - DF

O Ministério do Planejamento, Orçamento e Gestão e o Conselho Nacional de Secretários Estaduais de Administração - CONSAD reunidos em Brasília/DF, nos dias 26, 27 e 28 de maio de 2008, por ocasião da realização do Congresso CONSAD de Gestão Pública, resolvem registrar nesta Carta de Brasília as principais preocupações e diretrizes que devem orientar as estratégias e as ações em prol da construção de um pacto para melhorar a gestão pública.

O Ministério do Planejamento, Orçamento e Gestão e o CONSAD, considerando:

a. Que o Estado Brasileiro precisa cumprir sua função precípua de desenvolver políticas públicas direcionadas para a garantia da igualdade de oportunidades, dos direitos básicos de cidadania e do desenvolvimento sustentado, produzindo resultados eficientes e efetivos para a sociedade.

b. Que para dar conta das demandas da sociedade no contexto atual é necessário repensar a forma de organização e funcionamento do Estado.

c. Que diante das restrições de recursos públicos, de um lado, e do aumento das demandas sociais, de outro, fica clara a necessidade de se trabalhar de forma coordenada no âmbito dos Governos, em bases integradas e cooperativas, para obter maior sinergia entre as ações, com maior eficiência e efetividade das políticas públicas.

d. Que o arcabouço legal e institucional da administração pública é, de maneira geral, muito pesado e calcado em valores e práticas que, em muitos casos, estão ultrapassados.

e. Que a necessidade de se alcançar melhores resultados para a sociedade com maior qualidade do gasto público, ou seja, com a otimização da aplicação dos recursos disponíveis é consenso entre governo e sociedade.

\footnotetext{
${ }^{36}$ Disponível em www.gespublica.gov.br.
} 
f. Que é necessário que os governos atuem preventivamente, antecipando-se a problemas.

g. Que é urgente a inclusão do tema melhoria da gestão pública na agenda política dos Governos.

h. Que é fundamental orientar a atuação do Estado para resultados e com foco no cidadão.

Decidem,

1. Que o Ministério do Planejamento, Orçamento e Gestão e o CONSAD vão estabelecer uma parceria com o objetivo de propor e desenvolver ações voltadas a melhorar a gestão pública observando a agenda estratégica a seguir apresentada.

2. Submeter à sociedade a proposta de construção de um pacto para melhorar a gestão pública e articular uma frente parlamentar neste sentido.

A modernização da gestão implica em repensar a organização e o funcionamento da administração pública.

Nesse contexto, alguns tópicos merecem destaque na condição de elementos estruturais para o bom desempenho:

1. Gestão de pessoas - profissionalizar e capacitar continuamente a força de trabalho. Neste sentido, ganham especial importância: a criação e o gerenciamento de carreiras específicas alinhadas às necessidades da administração e pensadas em uma perspectiva estratégica; a definição de critérios para a ocupação dos cargos e funções comissionados; a introdução da lógica de gestão por competências para melhor alocação e uso dos talentos; e a implementação de sistemáticas de incentivo e responsabilização.

2. Modelos de gestão - simplificar os processos de trabalho, diminuindo o excesso de regras e controles; orientar a atuação do Estado para resultados e rever os mecanismos e instrumentos destinados a avaliar o desempenho institucional e a incentivar a boa gestão.

3. Instrumentos do ciclo de gestão - propiciar melhor articulação entre planejamento e orçamento e rever o modelo de gestão orçamentária de forma orientá-lo para resultados, tornando-o menos rígido.

4. Mecanismos de coordenação e integração - desenvolver e implementar mecanismos que propiciem e facilitem a coordenação das ações intra e governos, de forma a diminuir as duplicidades e sobreposições e possibilitar a articulação de esforços e o uso coordenado de recursos com vistas ao alcance dos resultados desejados.

5. Intensificar o uso de tecnologia, em especial estabelecer sistemas de informação, ferramentas de gestão - ferramentas de apoio ao gerenciamento gestão do conhecimento, bem como estimular o mapeamento, disseminação e incorporação de boas práticas de gestão.

6. Marco legal - rever o marco legal de forma a propiciar as condições estruturais necessárias e adequadas para a implementação de mudanças paradigmas, com maior flexibilidade gerencial, em direção à excelência em gestão pública. Neste contexto, merecem destaque: alteração da lei licitações; revisão das formas jurídico-institucionais vigentes; regulamentação do direito de greve no serviço público; regulamentação da relação parceria do Estado com a sociedade civil; regulamentação da contratualização de desempenho institucional; diretrizes de gestão participativa para estruturas colegiadas da Administração Pública Federal; e modernização da regulamentação que trata das transferências de recursos da União mediante convênios e contratos de repasse. 
7. Prevenção e combate à corrupção - reforçar os instrumentos de prevenção e combate à corrupção. Merecem destaque: a necessidade de reforçar institucionalizar mecanismos de transparência e controle social; adoção de gestão da ética como uma medida relevante; e instituição de sistemas de alerta para subsidiar as decisões de alocação de recursos e para acompanhamento e atuação prévios.

8. Realização de estudos e pesquisas para subsidiar as políticas e diretrizes para a modernização do Estado e para melhorar a gestão pública. Embora principais entraves e problemas da administração pública sejam conhecidos, existe enorme carência de estudos e pesquisas sistematizados sobre o assunto que possibilitem entender a dinâmica dos problemas e a qualificá-los e quantificá-los para subsidiar a elaboração de propostas de solução adequadas.

É fundamental investir na melhoria da gestão pública e dar visibilidade ao tema, de forma a incluí-lo nas agendas dos governos, mostrando a importância para que o Estado tenha condições efetivas de propiciar as respostas que a sociedade demanda.

O desafio de modernizar a gestão é de todos os três níveis de governo, de todos os poderes e também da sociedade, em particular dos seus setores organizados.

Brasília/ D.F., 28 de maio de 2008.

Paulo César Medeiros

Presidente do Consad.

Paulo Bernardo da Silva

Ministro do Estado do Planejamento, Orçamento e Gestão. 